Article

\title{
Reaching the Monophyly: Re-Evaluation of the Enigmatic Species Tenuibiotus hyperonyx (Maucci, 1983) and the Genus Tenuibiotus (Eutardigrada)
}

\author{
Daniel Stec ${ }^{1,2, *(D)}$ and Witold Morek ${ }^{2}$ iD \\ 1 Institute of Systematics and Evolution of Animals, Polish Academy of Sciences, \\ Sławkowska 17, 31-016 Kraków, Poland \\ 2 Department of Invertebrate Evolution, Institute of Zoology and Biomedical Research, Faculty of Biology, \\ Jagiellonian University, Gronostajowa 9, 30-387 Kraków, Poland; wmorek@op.pl \\ * Correspondence: daniel.stec@isez.pan.krakow.pl
}

Citation: Stec, D.; Morek, W. Reaching the Monophyly: Re-Evaluation of the Enigmatic Species Tenuibiotus hyperonyx (Maucci, 1983) and the Genus Tenuibiotus (Eutardigrada). Animals 2022, 12, 404. https://doi.org/10.3390/ani12030404

Academic Editor: Mirko Di Febbraro

Received: 12 January 2022

Accepted: 29 January 2022

Published: 8 February 2022

Publisher's Note: MDPI stays neutral with regard to jurisdictional claims in published maps and institutional affiliations.

Copyright: (C) 2022 by the authors. Licensee MDPI, Basel, Switzerland. This article is an open access article distributed under the terms and conditions of the Creative Commons Attribution (CC BY) license (https:// creativecommons.org/licenses/by/ $4.0 /)$.
Simple Summary: The tardigrade species Tenuibiotus hyperonyx (Maucci, 1982) was described forty years ago from the highest mountain of the Sella Group within the Dolomites (Italy), and so far, it is known only from its type locality. Due to the morphological characters of the claws, it has been included in the genus Tenuibiotus (Pilato \& Lisi, 2011). By conducting the integrative and phylogenetic analyses, we pinpointed the phylogenetic position of the species, which turned out to be positioned within the genus Diaforobiotus Guidetti et al., 2016. As the phenotypic characters of the examined species fit the diagnosis of this genus, we proposed a new combination, Diaforobiotus hyperonyx (Maucci, 1982) comb. nov. Furthermore, we looked more closely for the morphological diversity noted within the genus Tenuibiotus, clarifying phenotypic uncertainties regarding Tenuibiotus willardi (Pilato, 1977) and Tenuibiotus bozhkae Pilato, Kiosya, Lisi, Inshina \& Biserov, 2011. This action leads to uniformization of the genus diagnosis from the morphological point of view, which brings it closer to being considered as monophyletic.

\begin{abstract}
Revisions and redescriptions of taxa described in the past and that are now categorized as insufficiently diagnosed often play a crucial role in making further progress in modern taxonomy in many groups of organisms. Here we revised an enigmatic tardigrade species Tenuibiotus hyperonyx (Maucci, 1983) based on the newly discovered topotypic population from the Italian Alps. We performed an integrative analysis of morphological and genetic data in order to present an upgraded species description and elucidate its phylogenetic position. Our results enabled us to confidently place T. hyperonyx within the family Richtersiusidae, as a member of the genus Diaforobiotus. This change, together with a re-assessment of microphotographs of the Tenuibiotus willardi (Pilato, 1977) and Tenuibiotus bozhkae Pilato, Kiosya, Lisi, Inshina \& Biserov, 2011 types, led to the discussion on species composition with narrative taxa amendments for the taxonomic parties involved in the proposed alteration.
\end{abstract}

Keywords: Diaforbiotus; Dolomite Alps; integrative taxonomy; Macrobiotoidea; Tardigrada; taxonomic revision

\section{Introduction}

Tardigrades are microinvertebrates (body size rarely exceeding $1 \mathrm{~mm}$ ) found mostly in mosses and lichens [1]. The phylum comprises almost 1400 species; however, the real number of taxa that can be recognized in this group seems much higher, as each year brings dozens of new species that are being described and formally named [2-4]. Over the last ten years, the implementation of molecular techniques and taxonomic analyses by means of an integrative approach have accelerated the emergence of new species being characterized 
morphologically and genetically in detail, e.g., [5-12]. The acquisition and accumulation of genetic data tightly associated with phenotypic information enhanced studies on two major subjects in tardigrade taxonomy: (i) The recognition and disentanglement of cryptic/pseudocryptic diversity, e.g., [13-19] and (ii) the construction of comprehensive molecular phylogenies at the family level or higher that considerably impacted tardigrade systematics, e.g., [20-30]. Notably, there were not only integrative descriptions of new species for science that have contributed greatly to these subjects' investigation, but also revisional notes with updated diagnoses and new information on already-known taxa, e.g., [31-37]. All these contributions explicitly underline the importance of being integrative when studying tardigrade systematics [38,39].

Macrobiotus hyperonyx Maucci, 1982 [40] was described from the highest mountain of the Sella Group (Piz Boè, $3152 \mathrm{~m}$ a.s.l) within the Dolomites (Italy), and so far, it is known only from its type locality. Due to the animal's morphology, it has been included within the informal tenuis-group by Maucci [41,42], which was later revised by Tumanov $[43,44]$. The morphological premises of the tenuis-type claw (a common tract distinctly longer compared to other macrobiotids and a short secondary branch forming an almost right angle with the primary branch) have been considered as a main diagnostic characteristic for the genus Tenuibiotus erected by Pilato and Lisi [45]. The genetic data for the genus Tenuibiotus are limited to the four taxa that were published in three scientific papers [29,46,47]. Only in the first work did the authors demonstrate the monophyly of these taxa in their extensive phylogenetic study on the family Macrobiotidae. However, it was noted that all these Tenuibiotus populations were morphologically uniform with a non-porous cuticle and two macroplacoids in the pharynx [29]. Therefore, as some of the taxa originally attributed to the genus exhibit pores in the cuticle or three macroplacoids in the pharynx, and these traits are known to have great importance for eutardigrade classification, Stec et al. [29] suggested Tenuibiotus with such taxa composition to be polyphyletic.

In this work, we rediscovered a topotypic population of Tenuibiotus hyperonyx (Maucci, 1982) [40] in the Dolomite Alps on which the integrative taxonomic analysis was performed. This included detailed morphological and morphometric examination under phase contrast and scanning electron microscopy (PCM and SEM, respectively) and sequencing of four molecular markers (18S rRNA, $28 \mathrm{~S}$ rRNA, ITS-2 and COI). Given that T. hyperonyx exhibits pores in the body cuticle, we were able to test the hypothesis on Tenuibiotus polyphyly by elucidating its phylogenetic position. Additionally, the examination of microphotographs of the Tenuibiotus willardi (Pilato, 1977) [48] types enabled us to verify the presence of taxa possessing three macroplacoids in the pharynx within the genus.

\section{Material and Methods}

\subsection{Samples and Specimens}

Four moss or moss + lichen samples containing T. hyperonyx were collected from rocks at the nival zone in Trento (the Dolomites, Piz Boè; all at ca. $3000 \mathrm{~m}$ a.s.l.) by Witold Morek and Katarzyna Vončina on 18 July 2020 (Table 1). The samples were examined for tardigrades according to Stec et al. [49]. Other tardigrades present in the samples included Cornechiniscus holmeni (Petersen, 1951) [50], Echiniscus granulatus (Doyère, 1840) [51], and representatives of the genera Milnesium, Pseudechiniscus, and Richtersius. Extracted animals and eggs were divided into several groups used for different analyses, i.e., morphological analysis in PCM and SEM, as well as DNA sequencing (Table 1). Two additional specimens of Crenubiotus sp. from a Greenlandic moss sample (Sermersooq; $74^{\circ} 29^{\prime} 0.766^{\prime \prime} \mathrm{N}$, $20^{\circ} 32^{\prime} 18.308^{\prime \prime}$ W; 77 m a.s.l.; moss from soil; tundra; 07.2021; coll. Michał Kolasa) were sequenced in order to increase our phylogenetic dataset. 
Table 1. Information on moss samples containing specimens of T. hyperonyx analyzed in the present study (A stands for animals and E stands for eggs).

\begin{tabular}{|c|c|c|c|c|c|}
\hline \multirow{2}{*}{ Sample Code } & \multirow{2}{*}{ Sample Type } & \multirow{2}{*}{ Coordinates } & \multicolumn{3}{|c|}{ Analyses } \\
\hline & & & PCM & SEM & DNA \\
\hline IT.339 & moss & $\begin{array}{c}46^{\circ} 30^{\prime} 29.19^{\prime \prime} \mathrm{N} \\
11^{\circ} 49^{\prime} 41^{\prime \prime} \mathrm{E}\end{array}$ & $6 \mathrm{~A}+0 \mathrm{E}$ & $0 \mathrm{~A}+0 \mathrm{E}$ & $1 \mathrm{~A}+0 \mathrm{E}$ \\
\hline IT.341 & moss & $\begin{array}{l}46^{\circ} 30^{\prime} 26.9^{\prime \prime} \mathrm{N} \\
11^{\circ} 49^{\prime} 38.4^{\prime \prime} \mathrm{E}\end{array}$ & $13 \mathrm{~A}+0 \mathrm{E}$ & $0 \mathrm{~A}+0 \mathrm{E}$ & $1 \mathrm{~A}+0 \mathrm{E}$ \\
\hline IT.344 & moss + lichen & $\begin{array}{c}46^{\circ} 30^{\prime} 23.23^{\prime \prime} \mathrm{N} \\
11^{\circ} 49^{\prime} 31.8^{\prime \prime} \mathrm{E}\end{array}$ & $18 \mathrm{~A}+2 \mathrm{E}$ & $14 \mathrm{~A}+1 \mathrm{E}$ & $1 \mathrm{~A}+0 \mathrm{E}$ \\
\hline IT.345 & moss & $\begin{array}{c}46^{\circ} 30^{\prime} 23.23^{\prime \prime} \mathrm{N} \\
11^{\circ} 49^{\prime} 31.8^{\prime \prime} \mathrm{E}\end{array}$ & $9 \mathrm{~A}+1 \mathrm{E}$ & $0 \mathrm{~A}+0 \mathrm{E}$ & $1 \mathrm{~A}+0 \mathrm{E}$ \\
\hline
\end{tabular}

\subsection{DNA Sequencing}

DNA was extracted from individual animals following a Chelex ${ }^{\circledR} 100$ resin (BioRad, Warsaw, Poland) extraction method by Casquet et al. [52] with modifications described in detail in Stec et al. [35]. Each specimen was mounted in water and examined under light microscopy prior to DNA extraction. We sequenced four DNA fragments, three nuclear (18S rRNA, 28S rRNA, ITS2) and one mitochondrial (COI). All fragments were amplified and sequenced according to the protocols described in Stec et al. [35]; primers with original references are listed in Table 2. Sequencing products were read with the ABI 3130xl sequencer at the Molecular Ecology Lab, Institute of Environmental Sciences of the Jagiellonian University, Kraków, Poland. Newly obtained sequences were submitted to NCBI GenBank (see "Results" section and Table 3). Sequences in this study were processed and handle in BioEdit ver. 7.2.5 [53].

Table 2. Primers with their original references used for amplification of the four DNA fragments sequenced in the study.

\begin{tabular}{|c|c|c|c|c|}
\hline DNA Marker & $\begin{array}{l}\text { Primer } \\
\text { Name }\end{array}$ & $\begin{array}{c}\text { Primer } \\
\text { Direction }\end{array}$ & Primer Sequence $\left(5^{\prime}-3^{\prime}\right)$ & Primer Source \\
\hline \multirow[b]{2}{*}{ 18S rRNA } & 18S_Tar_Ff1 & forward & AGGCGAAACCGCGAATGGCTC & \multirow{2}{*}{ [54] } \\
\hline & 18S_Tar_Rr1 & reverse & GCCGCAGGCTCCACTCCTGG & \\
\hline \multirow{2}{*}{ 28S rRNA } & 28S_Eutar_F & forward & ACCCGCTGAACTTAAGCATAT & \multirow{2}{*}[55,56]{} \\
\hline & 28SR0990 & reverse & CCTTGGTCCGTGTTTCAAGAC & \\
\hline \multirow{2}{*}{ ITS-2 } & ITS2_Eutar_Ff & forward & CGTAACGTGAATTGCAGGAC & \multirow{2}{*}{ [13] } \\
\hline & ITS2_Eutar_Rr & reverse & TCCTCCGCTTATTGATATGC & \\
\hline \multirow{2}{*}{ COI } & LCO1490-JJ & forward & CHACWAAYCATAAAGATATYGG & \multirow{2}{*}{ [57] } \\
\hline & HCO2198-JJ & reverse & AWACTTCVGGRTGVCCAAARAATCA & \\
\hline
\end{tabular}

Table 3. GenBank accession numbers of the DNA sequences used for phylogeny reconstruction.

\begin{tabular}{|c|c|c|c|c|c|}
\hline Species & 18S rRNA & $28 S$ rRNA & COI & ITS-2 & Sources \\
\hline Hypsibius exemplaris & MG800327 & MG800337 & MG818724 & MG800336 & [58] \\
\hline Ramazzottius subanomalus & MF001997 & MF001998 & MF001999 & MG432819 & [54] \\
\hline Bertolanius volubilis & HQ604918 & - & AY598769 & - & {$[20,59]$} \\
\hline Bertolanius nebulosus & GQ849023 & - & - & - & [60] \\
\hline Eohypsibius nadjae & HQ604921 & - & - & - & [20] \\
\hline Minibiotus ioculator & MT023998 & МT024041 & МТ023412 & МT024000 & [35] \\
\hline Minibiotus pentannulatus & MT023999 & MT024042 & MT023413 & MT024001 & [35] \\
\hline
\end{tabular}


Table 3. Cont.

\begin{tabular}{|c|c|c|c|c|c|}
\hline Species & 18S rRNA & 28S rRNA & COI & ITS-2 & Sources \\
\hline Tenuibiotus voronkovi & KX810045 & KX810049 & KX810042 & KX810046 & [46] \\
\hline Tenuibiotus zandrae & MN443040 & MN443035 & MN444827 & MN443038 & [47] \\
\hline Paramacrobiotus areolatus & MH664931 & MH664948 & MH675998 & MH666080 & [17] \\
\hline Paramacrobiotus fairbanksi & MH664941 & MH664950 & MH676011 & MH666090 & [17] \\
\hline Macrobiotus shonaicus & MG757132 & MG757133 & MG757136 & MG757134 & [61] \\
\hline Macrobiotus caelestis & MK737073 & MK737071 & MK737922 & MK737072 & [62] \\
\hline Xerobiotus pseudohufelandi & HQ604989 & - & AY598776 & - & {$[20,59]$} \\
\hline Mesobiotus harmsworthi & MH197146 & MH197264 & MH195150 & MH197154 & [63] \\
\hline Mesobiotus dilimanensis & MN257048 & MN257049 & MN257047 & MN257050 & {$[64]$} \\
\hline Richtersius coronifer NO.385 & MH681760 & MH681757 & MH676053 & MH681763 & [18] \\
\hline Richtersius aff. coronifer GR.008 & MK211386 & MK211384 & MK214323-5 & MK211380-1 & [18] \\
\hline Richtersius aff. coronifer IT.120 & MH681761 & MH681758 & MH676054 & MH681764 & [18] \\
\hline Richtersius aff. coronifer IT.317 & MK211387 & MK211385 & MK214326-8 & MK211382-3 & [18] \\
\hline Richtersius aff. coronifer PL.247 & MH681762 & MH681759 & MH676055 & MH681765 & [18] \\
\hline Richtersius ziemowiti & MT241891 & MT241895 & MT246504 & MT241896 & [7] \\
\hline Diaforobiotus islandicus IS.042 & MT812470 & MT812461 & MT808072 & MT812597 & [27] \\
\hline Diaforobiotus sp. NO.386 & MT812471 & MT812463 & MT808074 & MT812598 & {$[27]$} \\
\hline Diaforobiotus sp. ID.517 & MT812472 & MT812462 & MT808073 & MT812599 & [27] \\
\hline Diaforobiotus hyperonyx IT.339 & OM179853 & OM179860 & OM151287 & OM179866 & This study \\
\hline Diaforobiotus hyperonyx IT.341 & OM179855 & OM179861 & OM151288 & OM179868 & This study \\
\hline Diaforobiotus hyperonyx IT.344 & OM179852 & OM179859 & OM151286 & OM179867 & This study \\
\hline Diaforobiotus hyperonyx IT.345 & OM179854 & OM179862 & OM151289 & OM179869 & This study \\
\hline Murrayon dianae & FJ435737 & FJ435762 & FJ435801 & - & [65] \\
\hline Murrayon cf. pullari IT.338 & MT812477 & MT812465 & MT808080 & MT812603 & [27] \\
\hline Murrayon pullari & GQ849026 & - & - & - & {$[60]$} \\
\hline Dactylobiotus parthenogeneticus FR.149 & MT373694 & МT373700 & MT373804 & MT374191 & [34] \\
\hline Dactylobiotus parthenogeneticus GB.003 & MT373693 & MT373699 & MT373803 & MT374190 & [34] \\
\hline Dactylobiotus parthenogeneticus PL.317 & MT373695 & MT373701 & MT373805-6 & MT374192 & {$[34]$} \\
\hline Dactylobiotus selenicus FI.073 & MT812476 & MT812466 & MT808076 & MT812602 & [27] \\
\hline Dactylobiotus ambiguus & GQ925676-7 & - & - & - & $\begin{array}{c}\text { Chen et al. } \\
\text { (unpub- } \\
\text { lished) }\end{array}$ \\
\hline Dactylobiotus ovimutans & MT136805 & - & MT132333 & - & {$[66]$} \\
\hline Dactylobiotus octavi & GQ849025 & - & - & - & \\
\hline Crenubiotus sp. GB.108 & MT812473 & МТ812467 & MT808077-8 & MT812604-5 & [27] \\
\hline Crenubiotus crenulatus NO.429 & MT812474 & МТ812463 & MT808079 & MT812606 & [27] \\
\hline Crenubiotus ruhesteini & $\begin{array}{c}\text { MW074384-5, } \\
\text { MW074387 }\end{array}$ & - & MW074336-8 & $\begin{array}{c}\text { MW074367-8, } \\
\text { MW074370 }\end{array}$ & [11] \\
\hline Crenubiotus sp. GL.001.01 & OM179850 & OM179857 & OM151284 & OM179864 & This study \\
\hline Crenubiotus sp. GL.001.02 & OM179851 & OM179858 & OM151285 & OM179865 & This study \\
\hline Adorybiotus granulatus & HQ604961-2 & - & - & - & [20] \\
\hline Adorybiotus cf. granulatus JP.008 & MT812475 & MT812464 & MT808075 & MT812600-1 & [27] \\
\hline
\end{tabular}

Sequences obtained in this study are bolded.

\subsection{Phylogenetic Analyses}

For phylogenetic analyses, we used a dataset that comprises concatenated DNA sequences of $18 \mathrm{~S}$ rRNA + $28 \mathrm{~S}$ rRNA + ITS-2 + COI markers. The BLAST search [67] with newly generated sequences as a query recovered their highest similarity with the Richtersiusidae Guidetti, Schill, Giovannini, Massa, Goldoni, Ebel, Förschler, Rebecchi \& Cesari, 2021 [11] taxa. Therefore, the phylogenetic dataset comprised taxa analyzed in Stec et al. [27] when erecting the family Adorybiotidae Stec, Vecchi \& Michalczyk, 2020 [27]. The dataset was supplemented with additional sequences of (i) Adorybiotidae and Richtersiusidae published after 2020, (ii) additional sequences of Murrayidae Guidetti, Rebecchi \& Bertolani, 2000 [68] and Eohypsibidae Bertolani \& Kristensen, 1987 [69] available in GenBank but unintentionally omitted in Stec et al. [27], as well as (iii) DNA sequences 
newly obtained in this study. Sequences were downloaded from GenBank, and the full list of accession numbers is given within Table 3 .

The sequences were aligned using the AUTO method (in the case of COI and ITS-2) and the Q-INS-I method (18S rRNA and 28S rRNA) in MAFFT version $7[70,71]$ and manually checked against non-conservative alignments in BioEdit. Then, the aligned sequences were trimmed to 1009 (18S rRNA), 832 (28S rRNA), 543 (ITS-2) and 658 (COI) bp. All COI sequences were translated into protein sequences in MEGA7 version 7.0 [72] to check against pseudogenes. The sequences were then concatenated in SequenceMatrix [73]. Using PartitionFinder version 2.1.1 [74] under the Akaike Information Criterion (AIC), and with a greedy algorithm [75] implemented within the software, we chose the best scheme of partitioning and substitution models for posterior phylogenetic analysis. We ran the analysis to test all possible models implemented in MrBayes and RAxML software. As the $\mathrm{COI}$ is a protein-coding gene, before partitioning, we divided our alignment of this marker into three data blocks constituting three separated codon positions.

Bayesian inference (BI) marginal posterior probabilities were calculated using MrBayes v3.2 [76]. Random starting trees were used, and the analysis was run for 10 million generations, sampling the Markov chain every thousand generations. An average standard deviation of split frequencies of $<0.01$ was used as a guide to ensure the two independent analyses had converged. The program Tracer v1.6 [77] was then used to ensure Markov chains had reached stationarity and to determine the correct 'burn-in' for the analysis, which was the first $10 \%$ of generations. The ESS values were greater than 200 and a consensus tree was obtained after summarizing the resulting topologies and discarding the 'burn-in'. The maximum-likelihood (ML) tree was computed using RAxML v8.0.19 [78]. The strength of support for internal nodes of the ML construction was measured using 1000 rapid bootstrap replicates. All final consensus trees were visualized with FigTree v.1.4.3 available from (http:/ / tree.bio.ed.ac.uk/software/figtree, accessed on 10 August 2018).

\subsection{Microscopy and Imaging}

Specimens for light microscopy were mounted on microscope slides following the protocol by Morek et al. [79]. Slides were examined under an Olympus BX53 light microscope with phase contrast (PCM), associated with an Olympus DP74 digital camera. Immediately after mounting the specimens in the medium, slides were checked under PCM for the presence of males and females in the studied population $[61,80]$. Specimens for the SEM analysis were processed according to the protocol by Stec et al. [49]. Bucco-pharyngeal apparatuses were extracted following the protocol of Eibye-Jacobsen [81] as modified by Gasiorek et al. [82]. Specimens were examined under high vacuum in a Versa 3D DualBeam Scanning Electron Microscope (SEM) at the ATOMIN facility of the Jagiellonian University, Kraków, Poland. All figures were assembled in Corel Photo-Paint X6.

\subsection{Morphometry and Morphological Nomenclature}

All measurements are given in micrometers $(\mu \mathrm{m})$. The sample size was adjusted following recommendations in Stec et al. [83]. Structures were measured only if their orientation was suitable. Body length was measured from the anterior extremity to the end of the body, excluding the hind legs. The terminology used to describe the oral cavity armature and egg-shell morphology follows Michalczyk and Kaczmarek [84] and Kaczmarek and Michalczyk [85]. The macroplacoid length sequence is given according to Kaczmarek et al. [86] whereas morphological states of the cuticular bars on legs follow Kiosya et al. [36]. The buccal tube length and the level of the stylet support insertion point were measured according to Pilato [87]. The $p t$ index was calculated as the ratio of the length of a given structure to the length of the buccal tube expressed as a ratio [87]. Measurements of buccal tube widths, heights of claws heights and eggs follow Kaczmarek and Michalczyk [85]. The claw common tract index (cct) is the proportion of the height of the common tract of the claw (measured from the claw base to the separation point between the first and the second branch) to the total claw height expressed as a percentage [22]. 
Morphometric data were handled using the "Parachela" ver. 1.8 template available from the Tardigrada Register [88]. Eutardigrade taxonomy follows [11,20,27,29].

\subsection{Comparative Material}

Microphotographs of animals and eggs from the type series of T. hyperonyx from the Maucci collection (Civic Museum of Natural History of Verona, Verona, Italy) were kindly provided by Denis Tumanov. Additional microphotographs of the T. hyperonyx types were taken by Witold Morek and Piotr Gasiorek during their visit in 2017 to the Evolutionary Zoology Lab (Department of Life Sciences, University of Modena and Reggio Emilia). Microphotographs of animals and eggs from the type series of T. willardi from the Pilato and Binda collection as well as the Bertolani collection were kindly provided by Oscar Lisi and Matteo Vecchi, respectively. Microphotographs of the holotype and the paratype of Tenuibiotus bozhkae Pilato, Kiosya, Lisi, Inshina \& Biserov, 2011 [89] from the Pilato and Binda collection were kindly provided by Oscar Lisi.

\subsection{Availability of Data and Materials}

DNA sequences for the examined populations are deposited in GenBank (https://www.ncbi.nlm.nih.gov/genbank, accessed on 10 August 2018). Best-fit partitioning schemes and models suggested by PartitionFinder are given within Supplementary Materials SM.01. Raw Bayesian and Maximum Likelihood trees are given in the Newick format within Supplementary Materials SM.02. Raw morphometric measurements of the newly discovered topotypic population of T. hyperonyx are given in Supplementary Materials SM.03. A movie recording of an alive, gravid female of T. hyperonyx is given in Supplementary Materials SM.04.

\section{Results}

\subsection{Phylogenetic Position of T. hyperonyx}

The phylogenetic reconstructions performed with BI and ML methods showed identical topologies, with well-supported nodes in each final tree (Figure 1). The monophyletic superfamily Macrobiotoidea was represented by four well-supported clades representing four valid and monophyletic families: Macrobiotidae, Murrayidae, Adorybiotidae and Richtersiusidae. Specimens of Tenuibiotus hyperonyx analyzed in this study have been recovered as a member of the genus Diaforobiotus Guidetti et al., 2016 [22] staying in a sister relationship with all other Diaforobiotus species (Figure 1). Other Tenuibiotus taxa analyzed in this study have been recovered as valid members of the family Macrobiotidae (Supplementary Materials SM.02). Thus, by the placement of T. hyperonyx within the family Richtersiusidae and its morphological similarity to the genus Diaforobiotus, the species is further transferred and proposed with a new nomenclatural combination as follows: Diaforobiotus hyperonyx comb. nov. (Figure 1; see the next sections below for details). All Crenubiotus Lisi, Londoño \& Quiroga, 2020 [90] taxa, including the newly analyzed Greenlandic population, formed a well-supported clade within the family Adorybiotidae in the BI and ML analyses (Supplementary Materials SM.02). 


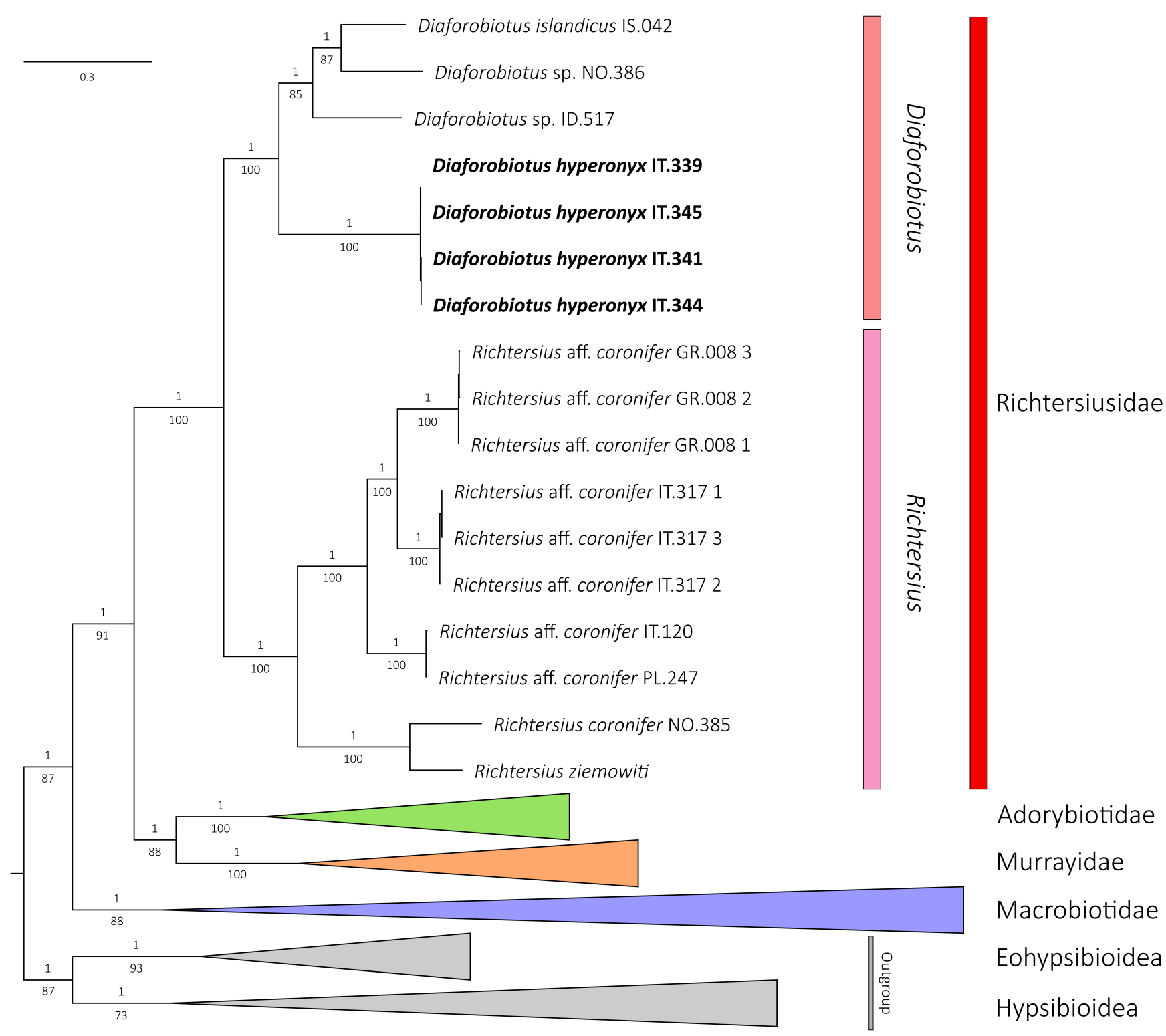

Figure 1. Phylogenetic reconstruction of the superfamily Macrobiotoidea based on concatenated $18 \mathrm{~S}$ rRNA + $28 \mathrm{~S}$ rRNA + ITS-2 + COI nucleotide sequences. Topology and branch length of BI reconstruction. Values above branches indicate BI posterior probabilities, values below branches indicate ML bootstrap support. Supports for intraspecific nodes are not shown. Newly sequenced specimens of D. hyperonyx comb. nov. are indicated by a bolded font.

\subsection{Amended Description of D. hyperonyx comb. nov.}

\subsubsection{Systematic and Taxonomic Account}

Phylum: Tardigrada Doyère, 1840 [51].

Class: Eutardigrada Richters, 1926 [91].

Order: Parachela Schuster et al., 1980 [92].

Superfamily: Macrobiotoidea Thulin, 1928 [93].

Family: Richtersiusidae Guidetti, Schill, Giovannini, Massa, Goldoni, Ebel, Förschler, Rebecchi \& Cesari, 2021 [11].

Genus: Diaforobiotus Guidetti, Rebecchi, Bertolani, Jönsson, Kristensen \& Cesari, 2016 [22].

Diaforobiotus hyperonyx comb. nov. (Maucci, 1982) [40] (Tables 4 and 5, Figures 2-13). 


\subsubsection{Material Examined}

In total, we examined 64 animals and 4 eggs. Specimens were mounted on microscope slides in Hoyer's medium (46 animals +3 eggs), fixed on SEM stubs $(14+1$, including four bucco-pharyngeal apparatuses) and processed for DNA sequencing (4 animals); details on topotypic locality and specific samples are given in Table 1 and the "Material and Methods" section.

\subsubsection{Slide and SEM Stubs Depositories}

Slides containing 24 animals and 2 eggs (from samples: IT.339 and IT.344) are deposited at the Institute of Systematics and Evolution of Animals (PAS); slides containing 22 animals and 1 egg (from samples: IT.341 and IT.345) and SEM stubs are deposited at the Institute of Zoology and Biomedical Research (JU).

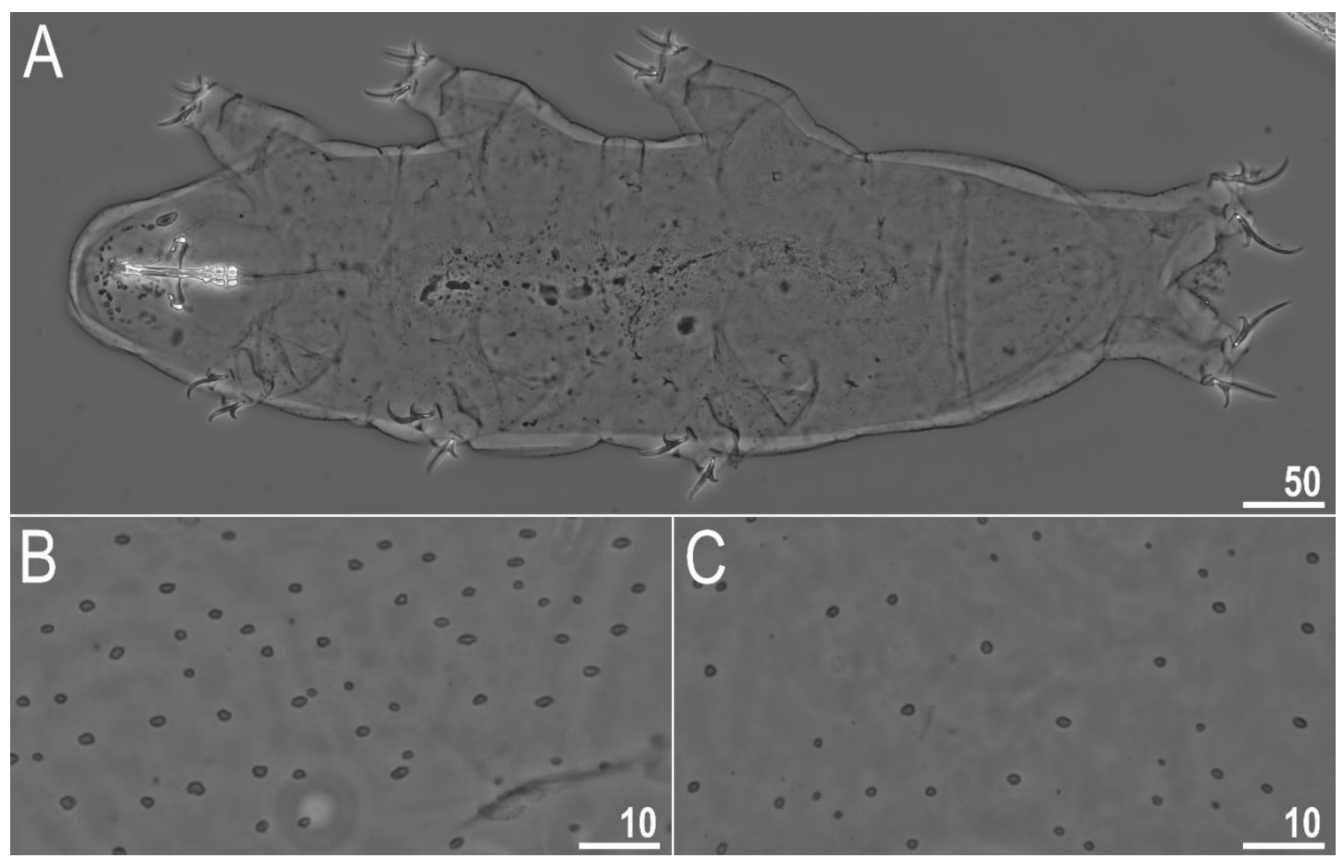

Figure 2. Diaforobiotus hyperonyx comb. nov. (Maucci, 1982): Habitus and cuticular pores seen in PCM: (A) Adult habitus, dorso-ventral projection; (B,C) cuticular pores on dorsal and ventral side of the body, respectively. Scale bars in $\mu \mathrm{m}$.
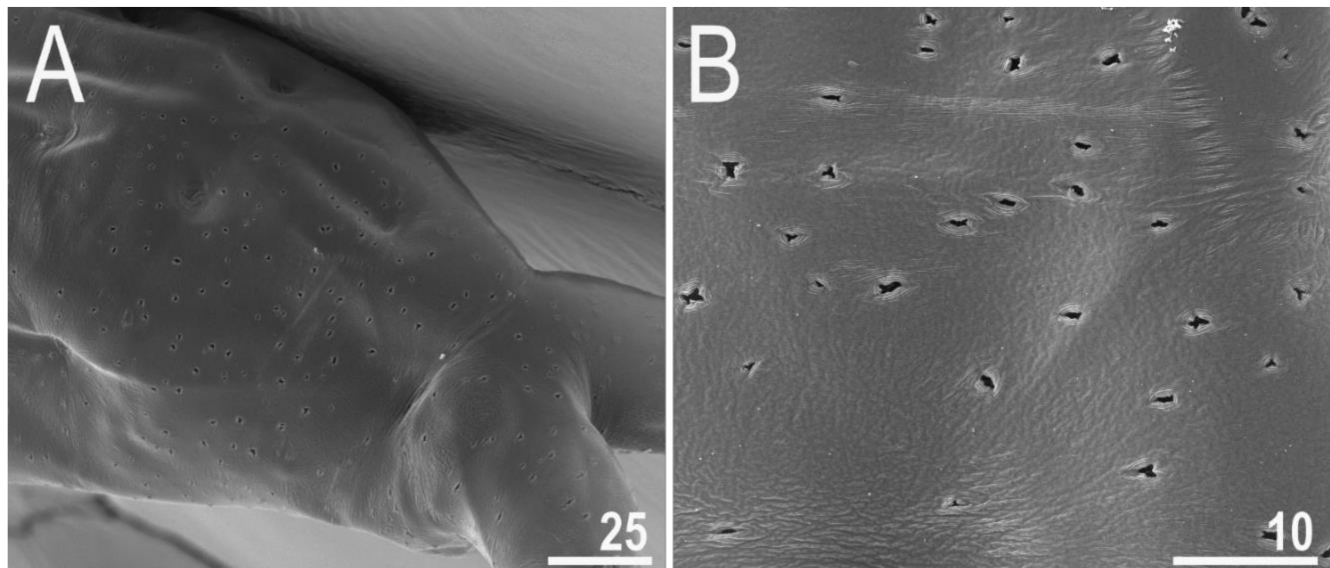

Figure 3. Diaforobiotus hyperonyx comb. nov. (Maucci, 1982): (A,B) Cuticular pores on dorsal side of the body seen in SEM. Scale bars in $\mu \mathrm{m}$. 


\subsubsection{Animals}

When alive, body pale yellow to light orange (Supplementary Materials SM.04); after fixation in Hoyer's medium, body transparent (Figure 2A). Large, black granular eyes present, also visible in specimens mounted in Hoyer's medium. Body cuticle smooth, without granulation but with circular or elliptical pores with uneven edges $(0.8-2.0 \mu \mathrm{m}$ in diameter) distributed randomly on the entire body cuticle with the largest pores present in the dorso-caudal cuticle (Figures $2 \mathrm{~B}, \mathrm{C}$ and $3 \mathrm{~A}, \mathrm{~B}$ ). Pores on the ventral side of the body less frequent than on the dorsal side (Figure 2B,C). Granulation on all legs absent (Figures $4 \mathrm{~A}-\mathrm{C}$ and $5 \mathrm{~A}-\mathrm{D}$ ). An obvious cuticular fold is present on the frontal side of each leg I-IV and clearly visible in PCM and SEM (Figures 4A-C and 5A-D). The pulvini are present on each leg I-III on the internal leg surface and are almost indistinct in PCM but clearly visible in SEM (Figure 5B).
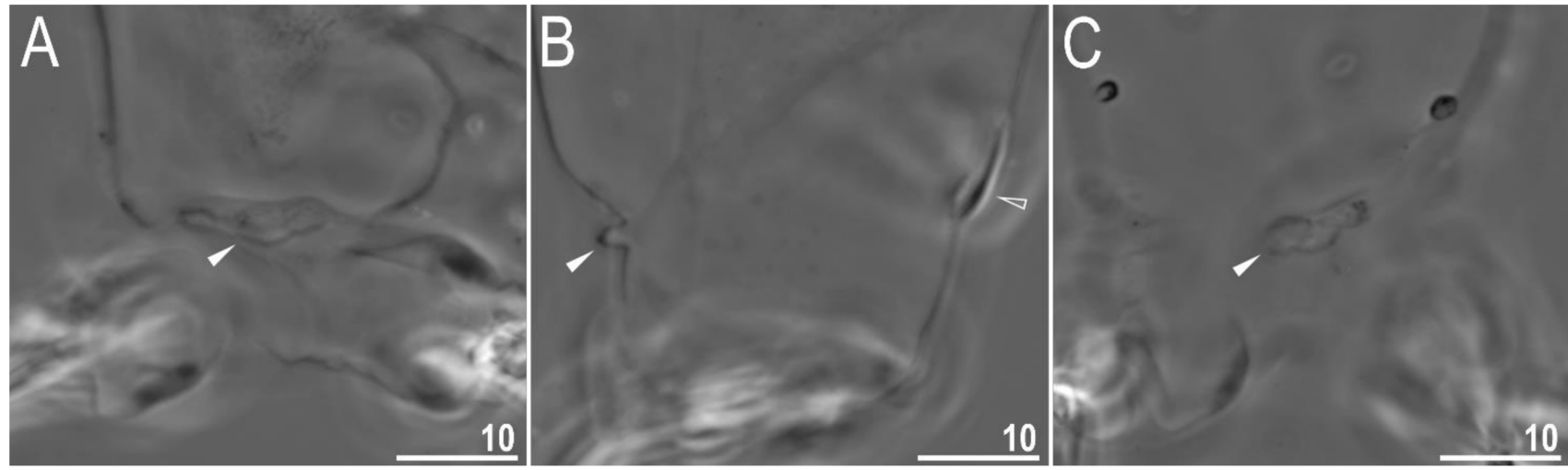

Figure 4. Diaforobiotus hyperonyx comb. nov. (Maucci, 1982): Leg cuticular structures seen in PCM: (A) Cuticular fold on the frontal surface of leg III; (B) optical midsection of leg II; (C) cuticular fold on the frontal surface of leg IV. Filled flat arrowheads indicate cuticular fold whereas empty flat arrowhead indicates cuticular bare above the claws. Scale bars in $\mu \mathrm{m}$.

Claws slender, of the richtersiusid type. Common tract with a system of internal septa, and with an evident stalk connecting the claw to the lunula (Figures $6 \mathrm{~A}-\mathrm{C}$ and $7 \mathrm{~A}, \mathrm{~B}$ ). The common tract nearly as long as the half of the entire claw height (Figures $6 \mathrm{~A}, \mathrm{C}$ and $7 \mathrm{~A}, \mathrm{~B}$ ). Primary and secondary branches form almost a right angle when bifurcating (Figures $6 \mathrm{~A}, \mathrm{C}$ and $7 \mathrm{~A}, \mathrm{~B}$ ). Primary branches with accessory points fitted tightly to the branch and thus indistinct in PCM but well visible only in SEM (Figures 6A,C and 7A,B). Large, wide lunulae present on all legs and only in hind legs equipped with clearly visible teeth (Figures $6 \mathrm{~A}-\mathrm{C}$ and $7 \mathrm{~A}, \mathrm{~B})$. A single continuous cuticular bar and paired muscle attachments present just above claws on legs I-III (Figures 4B, 5A,B, 6B and 7C). In PCM, the cuticular bar is indented towards the lunulae, with shaded extensions towards muscle attachments, whereas in SEM, it is visible as a continuous (only sometimes constricted in the middle) thickening (Figures 5A,B, 6B and 7C).

Mouth antero-ventral. Relatively short bucco-pharyngeal apparatus (Figures $8 \mathrm{~A}$ and $10 \mathrm{~A}$ ) with ten peribuccal lamellae, a rigid buccal tube, bended anteriorly, with the ventral lamina. Based on PCM observations, the oral cavity armature is poorly developed and composed only of the second and the third band of teeth (Figure 8B-F). However, the first band is present and visible only in SEM and composed of very small granular teeth positioned just below peribuccal lamellae (Figure 9A-C). In PCM, as well as in SEM, the second band of teeth is composed of several rows of granular teeth, of which the most posterior row comprises the larger teeth (Figures $8 \mathrm{~B}-\mathrm{E}$ and $9 \mathrm{~B}, \mathrm{C}$ ). The teeth of the third band are located within the posterior portion of the oral cavity, anteriorly to the buccal tube opening (Figures $8 \mathrm{~B}-\mathrm{F}$ and $9 \mathrm{~A}-\mathrm{C}$ ). The third band of teeth is divided into the dorsal and the ventral portion (Figures $8 \mathrm{~B}-\mathrm{F}$ and $9 \mathrm{~A}-\mathrm{C}$ ). The dorsal portion is composed of only one large tooth positioned in the very posterior portion of the oral cavity and far from the second band of 
teeth, whereas the ventral portion comprises small lateral ridges, between which a minute medial tooth is present (Figures $8 \mathrm{~B}-\mathrm{E}$ and $9 \mathrm{~B}, \mathrm{C}$ ). The ventral portion of the third band of teeth is especially faint in PCM (Figure $8 \mathrm{C}, \mathrm{E}$ ). The porous areas are present in the buccal crown (Figure 10B). In SEM, two depressions are visible on the ventral side of the buccal tube just below the stylet support insertion points (Figure 10C). Typically shaped furcae with enlarged basal portion also exhibiting two depressed circular areas just above the two caudal branches (visible only in SEM; Figure 10D). Pharynx spherical, with triangular apophyses, three anterior cuticular spikes (typically only two are visible in any given plane) and two rod-shaped macroplacoids $(2<1)$ (Figures $8 \mathrm{G}$ and 10E,F). The first macroplacoid is anteriorly narrowed and constricted in the middle, whereas the second has a sub-terminal constriction (Figures 8G and 10E,F). Microplacoid absent. Measurements of animals and statistics are presented in Table 4.
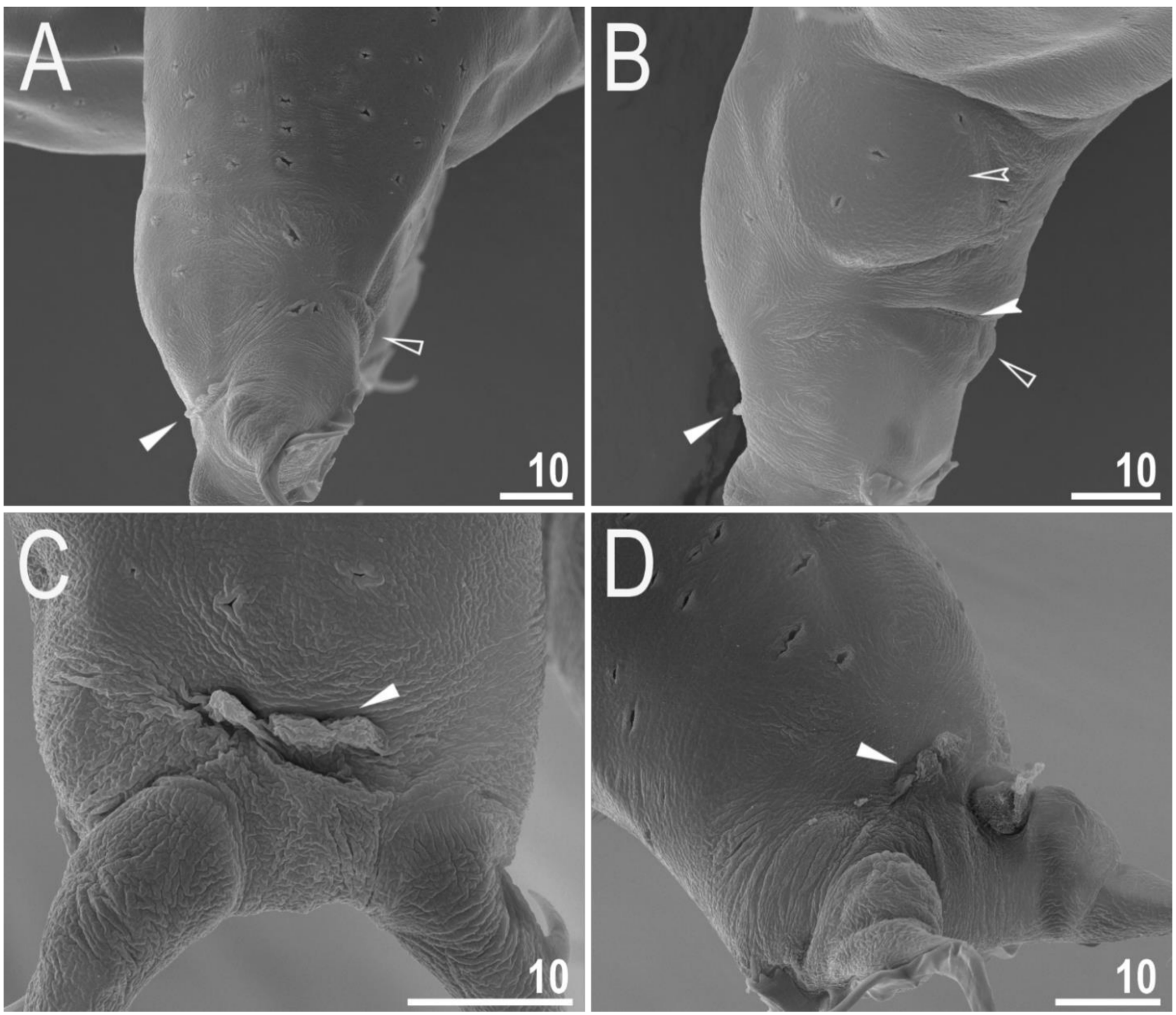

Figure 5. Diaforobiotus hyperonyx comb. nov. (Maucci, 1982): Leg cuticular structures seen in SEM: $(\mathbf{A}, \mathbf{B})$ Lateral view on the external and internal surface of leg II, respectively; (C) cuticular fold on the frontal surface of leg II; (D) cuticular fold on the frontal surface of leg IV. Filled flat arrowheads indicate cuticular fold, empty flat arrowheads indicate cuticular bare above the claws, filled indented arrowhead indicates muscle attachment above the cuticular bare whereas empty indented arrowhead indicates pulvinus. Scale bars in $\mu \mathrm{m}$. 


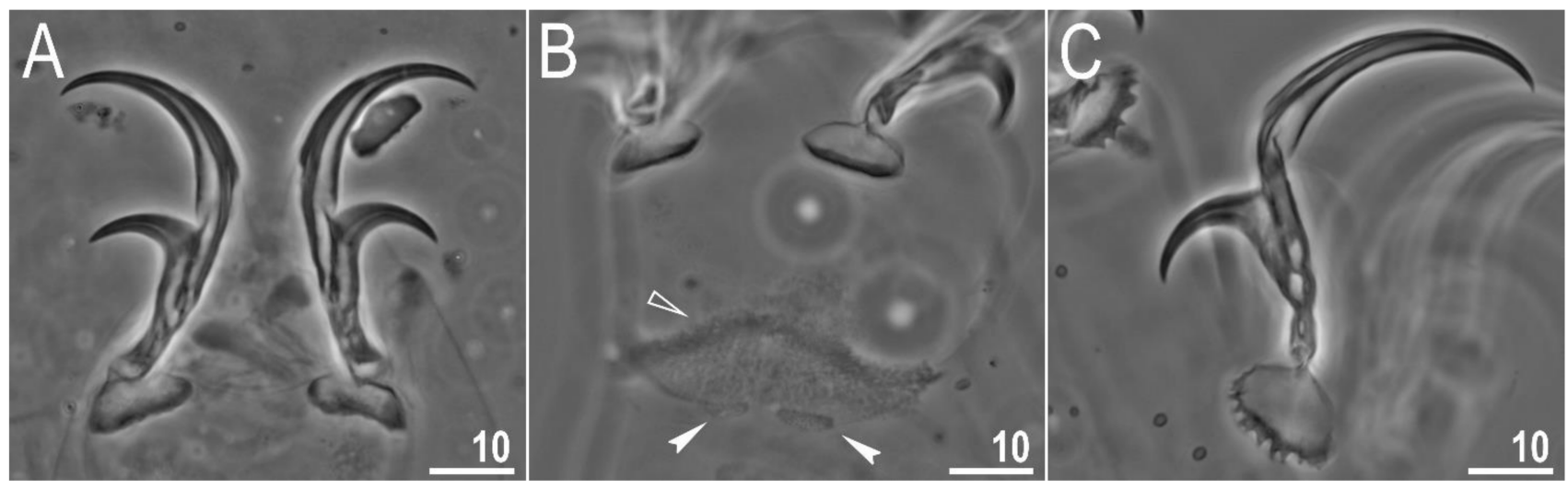

Figure 6. Diaforobiotus hyperonyx comb. nov. (Maucci, 1982): Claws seen in PCM: (A) Claws III; (B) lunulae of claws III and cuticular bar; (C) claws IV. Empty flat arrowhead indicates cuticular bare above the claws whereas filled indented arrowheads indicate double muscle attachments. Scale bars in $\mu \mathrm{m}$.
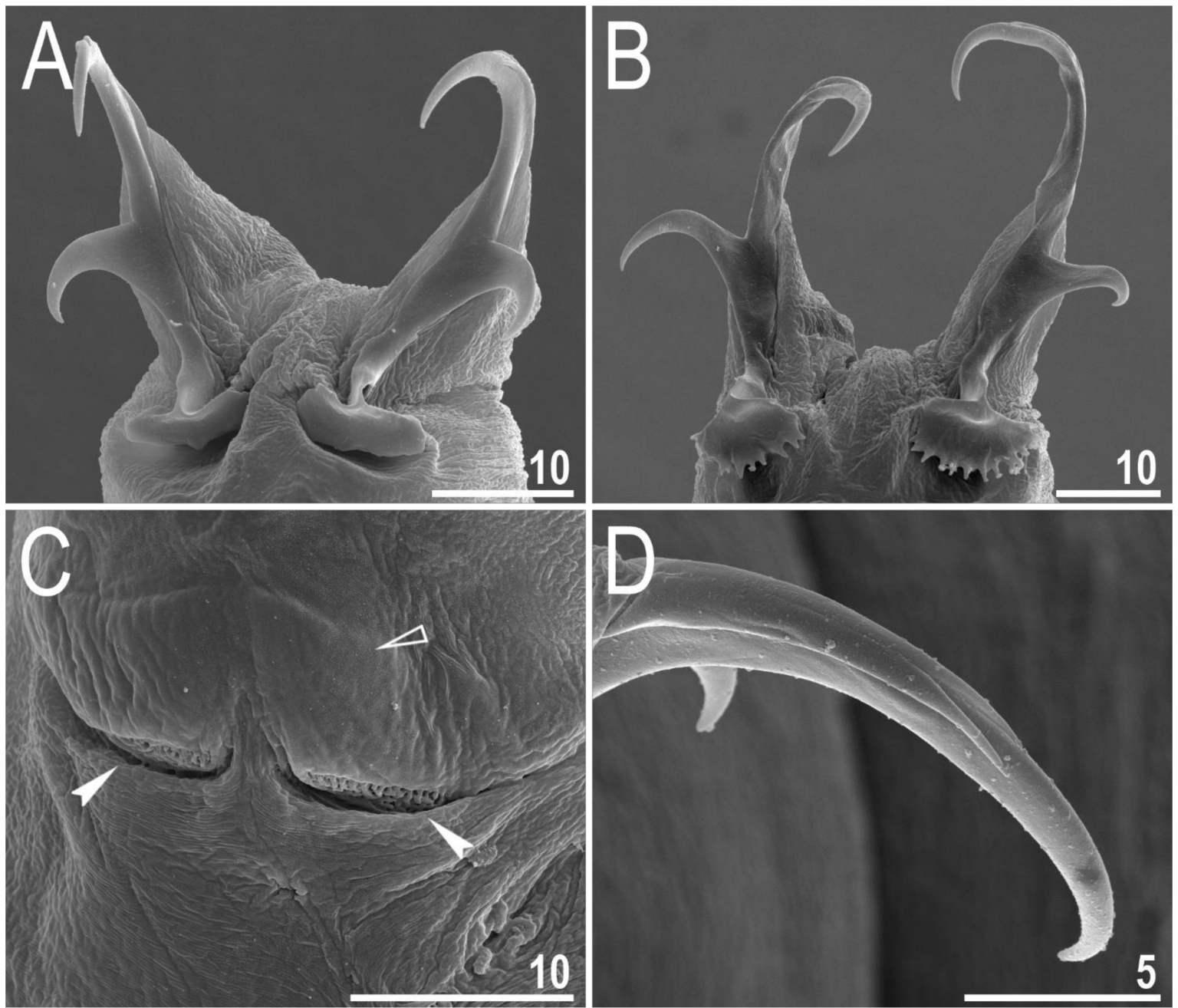

Figure 7. Diaforobiotus hyperonyx comb. nov. (Maucci, 1982): Claws seen in SEM: (A) Claws III; (B) claws IV; (C) cuticular bar and double muscle attachments above the claws; (D) details of primary claw branch and accessory points morphology. Empty flat arrowhead indicates cuticular bare above the claws whereas filled indented arrowheads indicate double muscle attachments. Scale bars in $\mu \mathrm{m}$. 

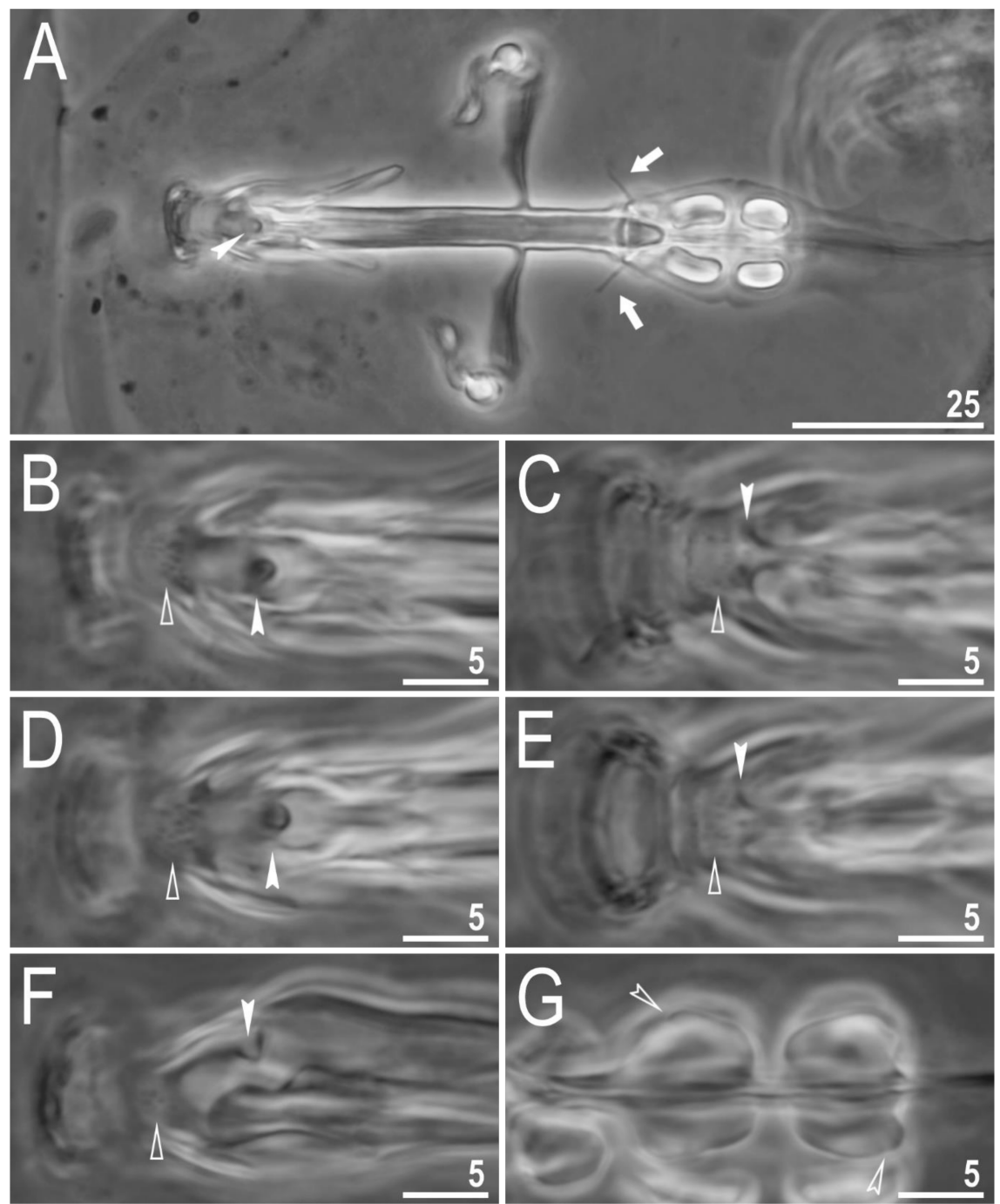

Figure 8. Diaforobiotus hyperonyx comb. nov. (Maucci, 1982): Bucco-pharyngeal apparatus seen in PCM: (A) Dorsal projection of the entire buccal apparatus; (B-E) dorsal (B,D) and ventral (C,E) views of the oral cavity armature of two different specimens; (F) lateral view of the anterior portion of the bucco-pharyngeal apparatus; $(G)$ ventral view of macroplacoids. Arrows indicate dorsal spikes, empty flat arrowheads indicate the second band of teeth, filled indented arrowheads indicate the third band of teeth whereas empty indented arrowheads indicate constrictions in macroplacoids. Scale bars in $\mu \mathrm{m}$.
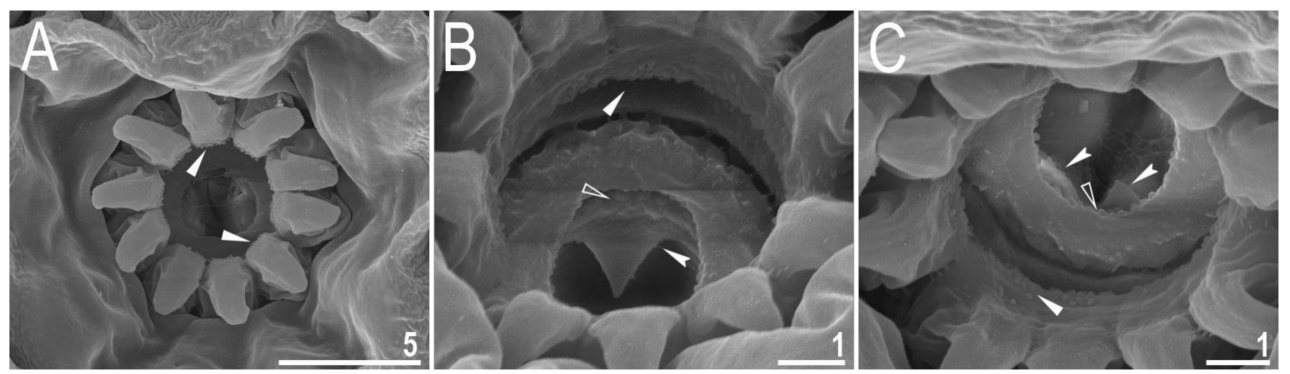

Figure 9. Diaforobiotus hyperonyx comb. nov. (Maucci, 1982): Oral cavity seen in SEM: (A) General view of the mouth opening; $(\mathbf{B}, \mathbf{C})$ dorsal and ventral views of the oral cavity armature seen from different angles. Filled flat arrowheads indicate the first band of teeth, empty flat arrowheads indicate the second band of teeth whereas filled indented arrowheads indicate the third band of teeth. Scale bars in $\mu \mathrm{m}$. 


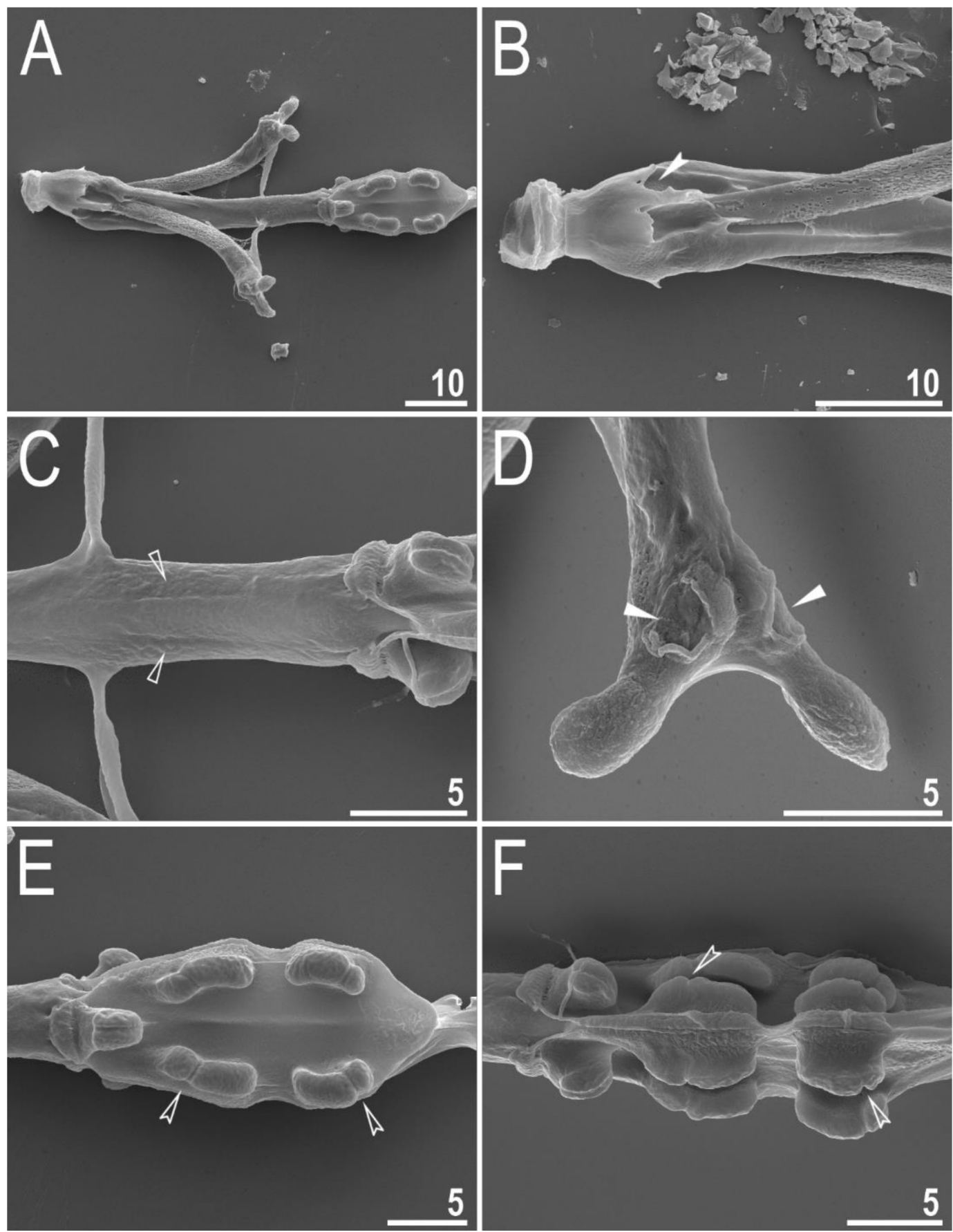

Figure 10. Diaforobiotus hyperonyx comb. nov. (Maucci, 1982): Bucco-pharyngeal apparatus seen in SEM: (A) General view of buccal apparatus; (B) details of buccal crown; (C) details of posterior portion of the buccal tube, ventral view; (D) stylet furca; (E,F) pharynx with macroplacoids. Filled indented arrowhead indicates perforated area in the buccal crown, empty flat arrowheads indicate depressions in the buccal tube below the stylet support insertion points, filled flat arrowheads indicate depressed circular areas in the basal portion of the stylet furca whereas empty indented arrowheads indicate constrictions in macroplacoids. Scale bars in $\mu \mathrm{m}$. 
Table 4. Measurements (in $\mu \mathrm{m}$ ) of selected morphological structures of animals from the topotypic population of D. hyperonyx comb. nov. (Maucci, 1982) mounted in Hoyer's medium; N-number of specimens/structures measured, RANGE refers to the smallest and the largest structure among all measured specimens; SD—standard deviation.

\begin{tabular}{|c|c|c|c|c|c|c|c|}
\hline \multirow{2}{*}{ Character } & \multirow{2}{*}{$\mathbf{N}$} & \multicolumn{2}{|c|}{ Range } & \multicolumn{2}{|c|}{ Mean } & \multicolumn{2}{|c|}{ SD } \\
\hline & & $\mu \mathrm{m}$ & $p t$ & $\mu \mathrm{m}$ & $p t$ & $\mu \mathrm{m}$ & $p t$ \\
\hline Body length & 18 & 449-961 & $1095-1888$ & 663 & 1394 & 137 & 186 \\
\hline \multicolumn{8}{|l|}{ Buccal tube } \\
\hline Buccal tube length & 18 & $34.8-52.6$ & & 47.2 & & 5.1 & \\
\hline Stylet support insertion point & 18 & $25.8-39.3$ & $72.0-74.7$ & 34.6 & 73.3 & 3.8 & 0.9 \\
\hline Buccal tube external width & 18 & $3.7-6.1$ & $10.2-11.8$ & 5.2 & 10.9 & 0.7 & 0.5 \\
\hline Buccal tube internal width & 18 & $2.0-3.3$ & $4.6-6.5$ & 2.7 & 5.7 & 0.4 & 0.6 \\
\hline Ventral lamina length & 17 & $19.0-28.7$ & $49.1-56.6$ & 25.7 & 53.6 & 2.7 & 2.5 \\
\hline \multicolumn{8}{|l|}{ Placoid lengths } \\
\hline Macroplacoid 1 & 18 & $5.4-9.9$ & $12.7-19.4$ & 7.5 & 15.8 & 1.1 & 1.3 \\
\hline Macroplacoid 2 & 18 & $4.0-8.7$ & $11.4-16.5$ & 6.1 & 12.8 & 1.1 & 1.1 \\
\hline Macroplacoid row & 18 & $10.4-18.8$ & $29.9-36.9$ & 15.4 & 32.4 & 2.1 & 1.6 \\
\hline \multicolumn{8}{|l|}{ Claw 1 heights } \\
\hline External base & 18 & $6.9-16.1$ & $16.6-31.6$ & 10.5 & 22.2 & 2.2 & 3.6 \\
\hline External primary branch & 18 & $15.3-32.1$ & $41.6-63.1$ & 23.4 & 49.2 & 4.6 & 5.7 \\
\hline External secondary branch & 13 & $7.9-16.1$ & $21.0-31.0$ & 11.5 & 24.2 & 2.0 & 2.7 \\
\hline External base/primary branch (cct) & 18 & $36.4-57.3$ & & 45.1 & & 5.9 & \\
\hline Internal base & 18 & $6.1-15.6$ & $17.5-30.6$ & 10.1 & 21.2 & 2.1 & 3.3 \\
\hline Internal primary branch & 18 & $14.5-31.4$ & $40.2-60.5$ & 22.4 & 47.1 & 4.2 & 5.1 \\
\hline Internal secondary branch & 13 & $6.1-15.3$ & $17.5-29.5$ & 11.0 & 23.0 & 2.2 & 3.1 \\
\hline Internal base/primary branch (cct) & 18 & $36.5-55.9$ & & 45.2 & & 5.8 & \\
\hline \multicolumn{8}{|l|}{ Claw 2 heights } \\
\hline External base & 13 & $7.6-18.5$ & $20.1-36.3$ & 12.1 & 25.6 & 2.8 & 3.9 \\
\hline External primary branch & 14 & $16.5-35.5$ & $45.7-69.7$ & 25.9 & 54.5 & 5.9 & 7.3 \\
\hline External secondary branch & 9 & $11.2-20.0$ & $25.9-39.3$ & 14.8 & 29.7 & 2.6 & 4.2 \\
\hline External base/primary branch (cct) & 13 & $40.3-54.7$ & & 47.1 & & 4.6 & \\
\hline Internal base & 17 & $7.0-16.8$ & $17.9-33.0$ & 11.3 & 23.9 & 2.5 & 3.5 \\
\hline Internal primary branch & 17 & $15.2-34.4$ & $42.1-67.6$ & 24.8 & 52.3 & 5.5 & 7.2 \\
\hline Internal secondary branch & 14 & $9.4-17.2$ & $21.7-33.8$ & 13.4 & 27.3 & 2.0 & 3.2 \\
\hline Internal base/primary branch (cct) & 17 & $37.0-55.6$ & & 46.1 & & 5.2 & \\
\hline \multicolumn{8}{|l|}{ Claw 3 heights } \\
\hline External base & 14 & $6.8-19.2$ & $19.5-37.7$ & 12.1 & 25.4 & 2.9 & 4.9 \\
\hline External primary branch & 14 & $15.7-37.1$ & $45.1-72.9$ & 26.4 & 55.4 & 5.2 & 7.1 \\
\hline External secondary branch & 10 & $11.6-20.6$ & $25.6-40.5$ & 14.0 & 28.9 & 2.5 & 4.3 \\
\hline External base/primary branch (cct) & 14 & $38.5-55.7$ & & 45.7 & & 5.8 & \\
\hline Internal base & 16 & $6.0-18.9$ & $17.2-37.1$ & 11.7 & 24.8 & 3.2 & 5.0 \\
\hline Internal primary branch & 16 & $15.7-37.0$ & $43.8-71.9$ & 25.5 & 54.0 & 6.0 & 8.2 \\
\hline Internal secondary branch & 11 & $11.0-19.5$ & $24.1-38.3$ & 13.7 & 28.0 & 2.4 & 4.0 \\
\hline Internal base/primary branch (cct) & 16 & $38.0-53.5$ & & 45.9 & & 6.2 & \\
\hline \multicolumn{8}{|l|}{ Claw 4 heights } \\
\hline Anterior base & 12 & $9.1-20.1$ & $22.8-39.5$ & 13.2 & 28.5 & 3.0 & 4.1 \\
\hline Anterior primary branch & 12 & $27.2-49.4$ & $62.8-97.1$ & 37.3 & 80.6 & 6.7 & 7.8 \\
\hline Anterior secondary branch & 11 & $11.0-24.4$ & $30.1-47.9$ & 15.9 & 34.4 & 3.8 & 5.0 \\
\hline Anterior base/primary branch (cct) & 12 & $30.6-44.9$ & & 35.4 & & 4.1 & \\
\hline Posterior base & 13 & $10.3-21.9$ & $23.2-43.0$ & 15.6 & 33.4 & 3.6 & 5.3 \\
\hline Posterior primary branch & 13 & $27.4-49.9$ & $63.3-98.0$ & 40.0 & 85.8 & 7.3 & 8.9 \\
\hline Posterior secondary branch & 12 & $12.4-25.3$ & $30.4-49.7$ & 19.2 & 40.3 & 4.0 & 5.9 \\
\hline Posterior base/primary branch (cct) & 13 & $30.9-46.7$ & & 38.9 & & 4.4 & \\
\hline
\end{tabular}




\subsubsection{Eggs}

Laid freely, yellowish to light orange (Supplementary Materials SM.04), spherical with conical processes and smooth egg surface without areolation, reticulation or lightrefracting dots (Figure 11A-D and Figure 12A-D). The process apices can sometimes exhibit faint nodular projection at the top (Figure 12B-D). Distal portions of the processes are covered by faint granulation: Dark dots of rough/jagged wall in the process midsection (PCM) / clear hemispheres (SEM) (Figure 11C,D and Figure 12A-D). The labyrinthine layer between the process walls as well as dark thickenings around process bases absent. Delicate micropores near the process bases rarely present and visible only in SEM (Figure 12B-D). Egg measurements and statistics are presented in Table 5.

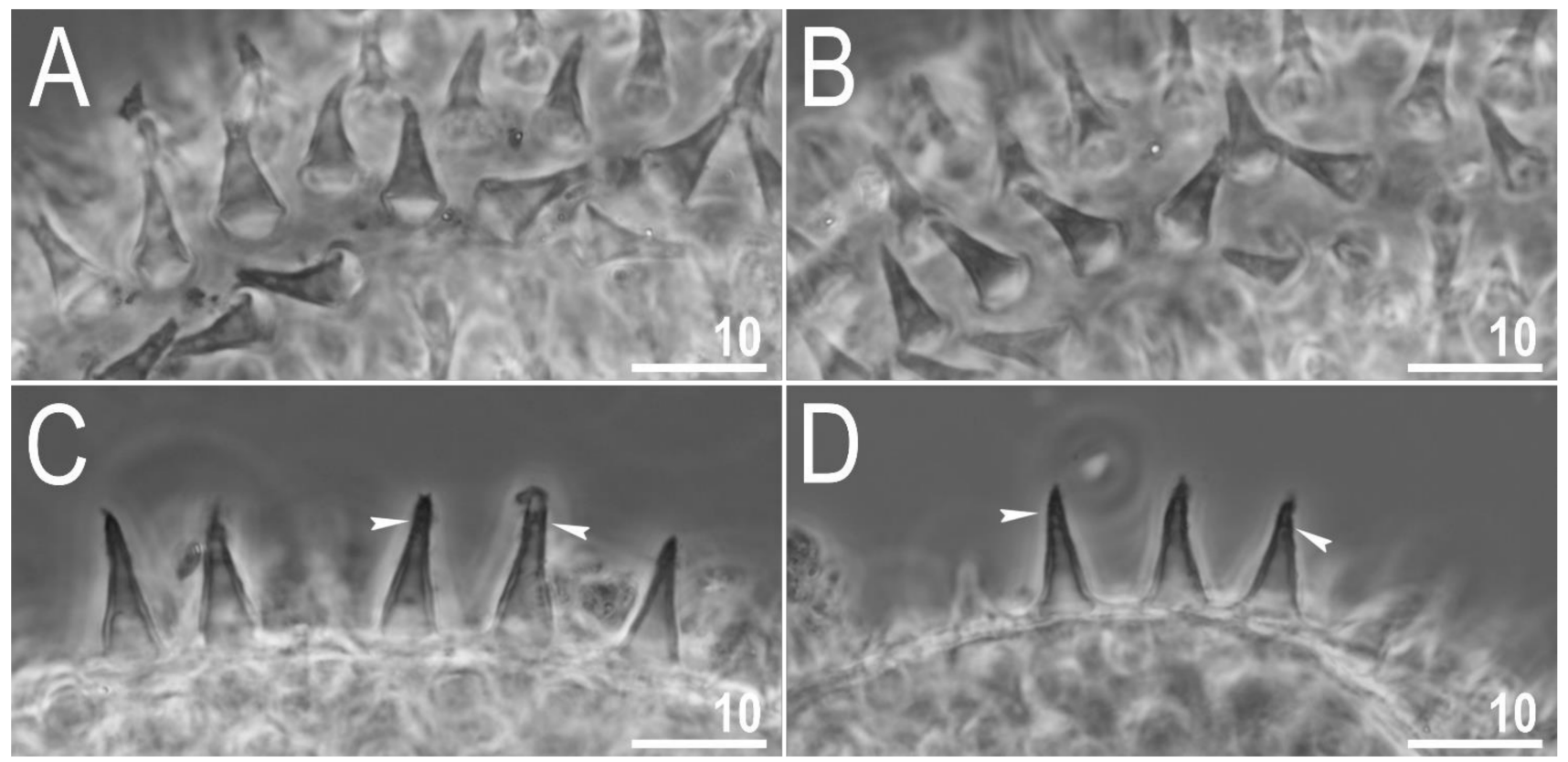

Figure 11. Diaforobiotus hyperonyx comb. nov. (Maucci, 1982): Eggs seen in PCM: (A,B) Details of egg processes and surface under a $\times 1000$ magnification; $(\mathbf{C}, \mathbf{D})$ midsection of the egg processes under a $\times 1000$ magnification. Filled indented arrowheads indicate granulation on the distal portion of egg processes visible as dark dots and/or rough processes margins. Scale bars in $\mu \mathrm{m}$. 

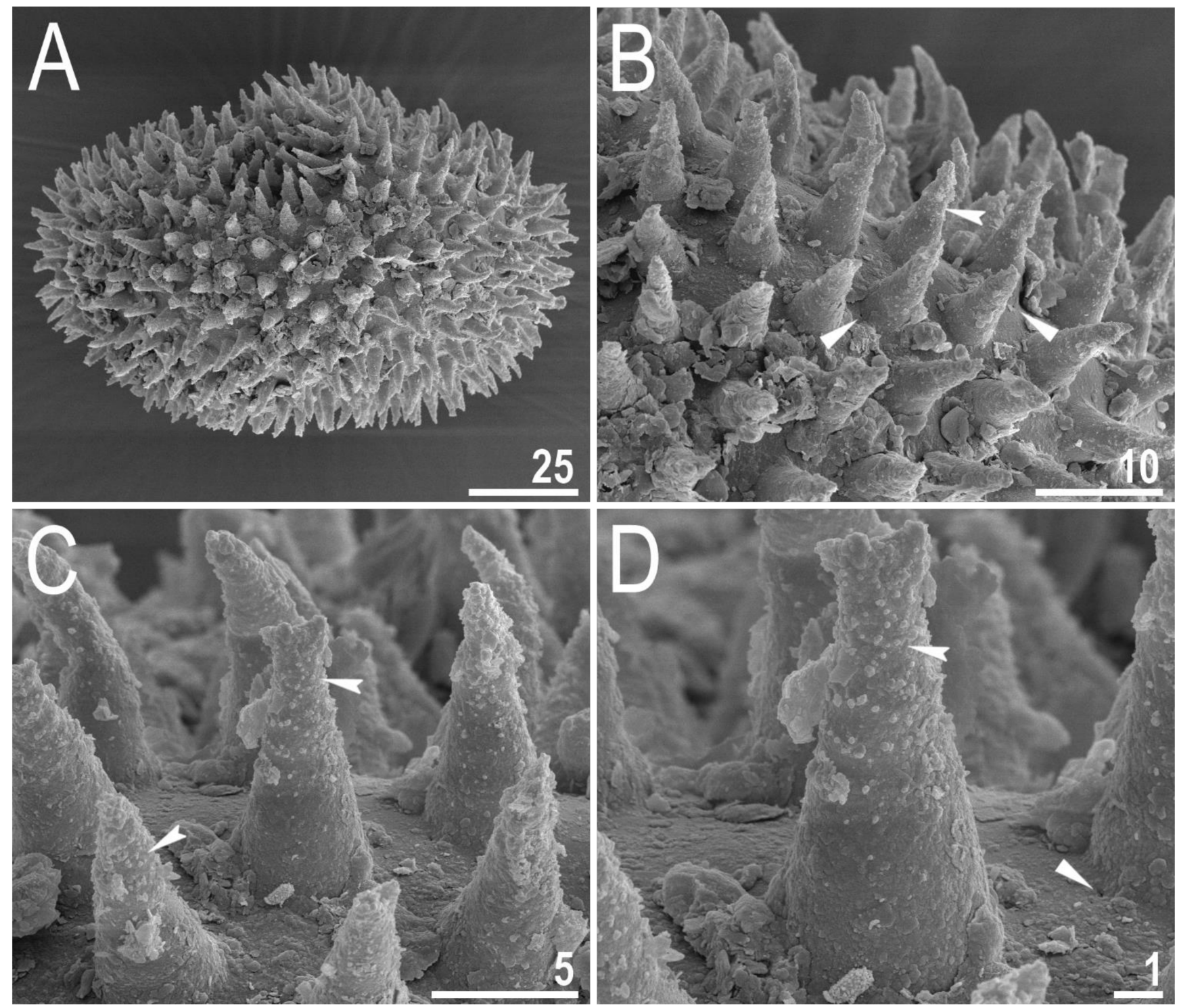

Figure 12. Diaforobiotus hyperonyx comb. nov. (Maucci, 1982): Egg seen in SEM: (A) General view of the entire egg; (B-D) morphological details of egg surface and egg processes. Filled indented arrowheads indicate granulation on the distal portion of egg processes whereas filled flat arrowheads indicates micropores in the egg surface near processes bases. Scale bars in $\mu \mathrm{m}$.

Table 5. Measurements (in $\mu \mathrm{m}$ ) of selected morphological structures of the eggs from the topotypic population of D. hyperonyx comb. nov. (Maucci, 1982) mounted in Hoyer's medium; all three eggs were damaged in permanent slides, thus the diameter and number of processes on the egg circumference cannot be measured/counted; N-number of eggs/structures measured, RANGE refers to the smallest and the largest structure among all measured specimens; SD—standard deviation.

\begin{tabular}{ccccc}
\hline Character & N & Range & Mean & SD \\
\hline Egg bare diameter & 0 & $?$ & $?$ & $?$ \\
Egg full diameter & 0 & $?$ & $?$ & $?$ \\
Process height & 9 & $9.4-11.9$ & 10.4 & 0.8 \\
Process base width & 9 & $4.0-5.5$ & 4.7 & 0.5 \\
Process base/height ratio & 9 & $39-50 \%$ & $46 \%$ & $4 \%$ \\
Inter-process distance & 9 & $2.7-4.9$ & 3.6 & 0.7 \\
Number of processes on the & 0 & $?$ & $?$ & $?$ \\
egg circumference & & & & \\
\hline
\end{tabular}




\subsubsection{Reproduction}

The examination of adults freshly mounted in Hoyer's medium revealed testes filled with spermatozoa in each of the four examined samples, confirming the species to be dioecious (Figure 13A,B). Any other secondary sexual phenotypic characters, e.g., gibbosities on the hind legs in males, absent.
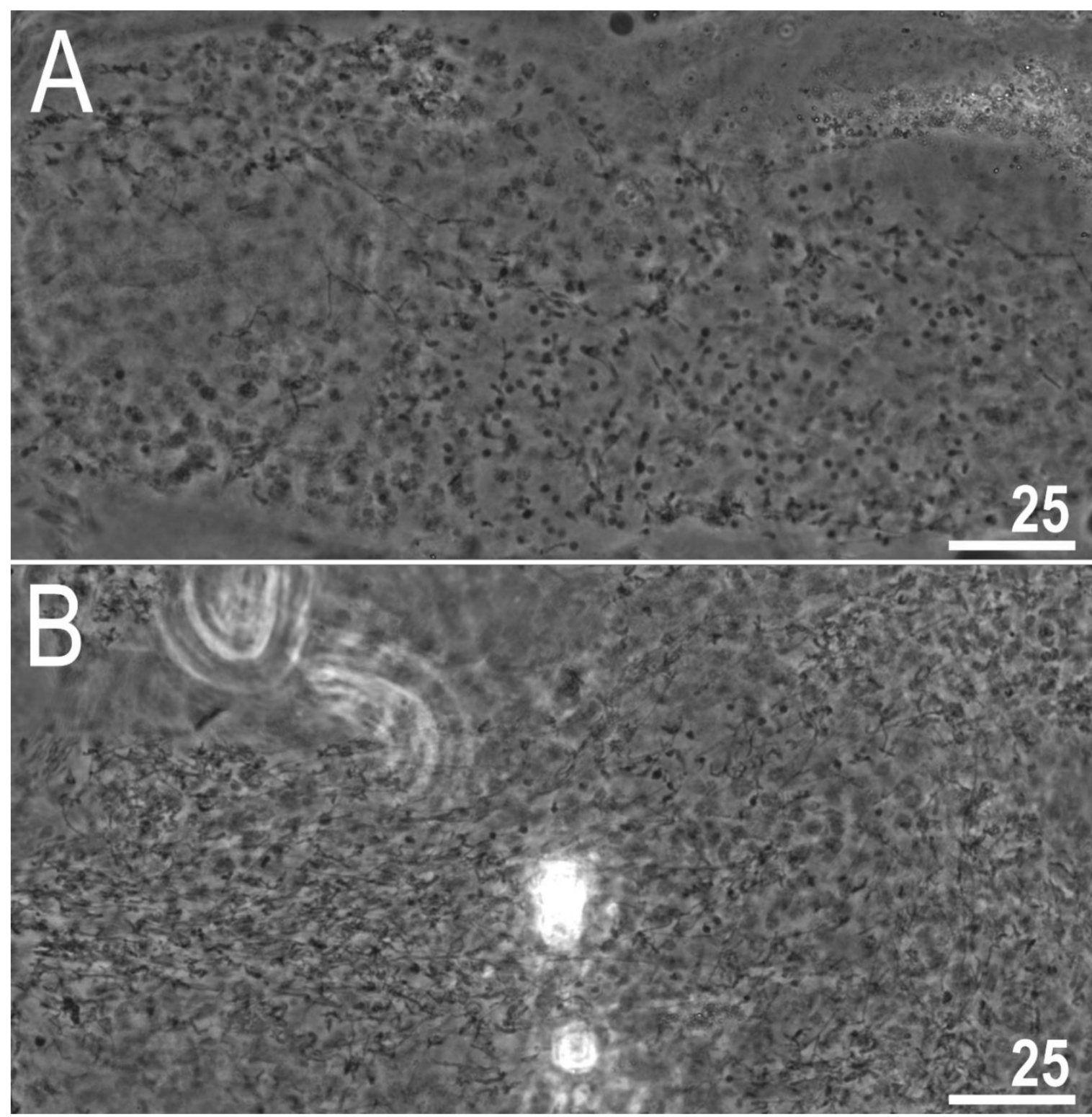

Figure 13. Diaforobiotus hyperonyx comb. nov. (Maucci, 1982): Testes filled with spermatozoa: (A) A male from sample IT.339; (B) a male from sample IT.344. Scale bars in $\mu \mathrm{m}$.

\section{Discussion}

Morphological information gathered in our integrative study on the newly discovered population, compared also with type specimens, fully support its identification as Tenuibiotus hyperonyx (Maucci, 1982) [40]. Based on the recovered phylogenetic position within the family Richtersiusidae as well as its phenotypic affinity to the genus Diaforobiotus, the species is proposed to be transferred to the later taxon. The proposed change requires amendments to the diagnosis of the family Richtersiusidae, which, among other characters, is now also defined by the presence of large teeth on all lunulae. Since Diaforobiotus hyperonyx comb. nov. exhibits teeth only in lunulae in the hind legs, the for- 
mer character cannot be exclusive for the family. This further brings our attention to the two recent papers focusing on the phylogenetic relationships between four genera, namely $D i$ aforobiotus, Richtersius Pilato \& Binda, 1989 [94], Adorybiotus Maucci \& Ramazzotti, 1981 [95] and Crenubiotus. Both these papers $[11,27]$ were published at approximately the same time and came up with different interpretations of the relationship between the mentioned taxa. Guidetti et al. [11] studied the phylogenetic position of the newly discovered Crenubiotus species, also pinpointing its classification within the family Richtersiusidae, whereas Stec et al. [27] phylogenetically analyzed two different Crenubiotus and one additional Adorybiotus populations. Both studies recovered the sister relationships between clades Adorybiotus + Crenubiotus and Murrayon + Dactylobiotus, with Richtersius + Diaforobiotus being a sister clade to this entire cluster [11,27]. However, only Stec et al. [27] proposed splitting the family Richtersiusidae and erected the new family Adorybiotidae that comprises Adorybiotus and Crenubiotus, with the main distinctive character being the absence and presence of microplacoid in these families, respectively [27]. The phylogenetic analysis with increased taxa sampling conducted in our study yielded even higher support for the scenario proposed by Stec et al. [27], further confirming the validity of the family Adorybiotidae (Figure 1, Supplementary Materials SM.02). Finally, it would be worth discussing the obvious elongation of the claw primary branches in the Diaforobiotus hyperonyx comb. nov., which make it distinct from all other Diaforobiotus populations recorded so far. This character could potentially constitute a clear diagnostic trait for a putative new genus, especially together with the recovered sister relationship between this species and remaining Diaforobiotus taxa (Figure 1). Nevertheless, we believe that, currently, the genus erection would be premature as the phylogenetic sampling of Diaforobiotus taxa is still scarce and the genus likely comprises at least several other species. Furthermore, the claw elongation in macrobiotids was recently reported to be caused most probably by the wet and icy environment [96]. The authors presented the phylogeny of the family Macrobiotidae demonstrating convergent evolution in claw elongation in the Macrobiotus ariekammensis complex and Mesobiotus barabanovi (Tumanov, 2005) [43], with both of them being deeply nested within their respective genera. The occurrence of Diaforobiotus hyperonyx comb. nov. in the high mountains (Dolomite Alps) further supports the hypothesis of environmental factors affecting the claw phenotypic changes in macrobiotids, constituting the third example of convergently evolving claws phenotypes within Macrobiotoidea.

As mentioned in the Introduction, although the genus Tenuibiotus was recovered to be monophyletic in the phylogeny presented by Stec et al. [29], it was suggested to still be polyphyletic due to the morphological heterogeneity of the included taxa at that time. The mixed morphological characters that led to such a suggestion were: (i) The presence or absence of cuticular pores and (ii) varying numbers of placoids in the pharynx. After transferring T. hyperonyx to the genus Diaforobiotus, all remaining taxa currently recognized in the genus Tenuibiotus (13 species) exhibit a non-porous cuticle, which signifies that this trait is a solid and uniform diagnostic character of the genus. The nomenclatural and classification change proposed by us also provided the second uniform morphological trait that characterizes all members of the genus Tenuibiotus - the presence of a microplacoid in the pharynx. Regarding the number of macroplacoids, the majority of genus members exhibit two macroplacoids in the pharynx, excluding two species, which were reported to have three macroplacoids. These are T. willardi and T. bozhkae. The original description of the first one reports three or two macroplacoids to be present in the type population [48]. However, the re-examination of the holotype and paratype bucco-pharyngeal apparatuses confirmed the presence of two macroplacoids in the pharynx (Figure 14A-C). Since the name-bearing specimen exhibits this trait and it is considered important in the tardigrade classification, it should be considered the primary character state of the nominal species. The original description of the second species indeed reports three macroplacoids [89] and, at the same time, indicates morphological similarity with Tenuibiotus ciprianoi (Guil, Guidetti \& Machordom, 2007) [97]. 

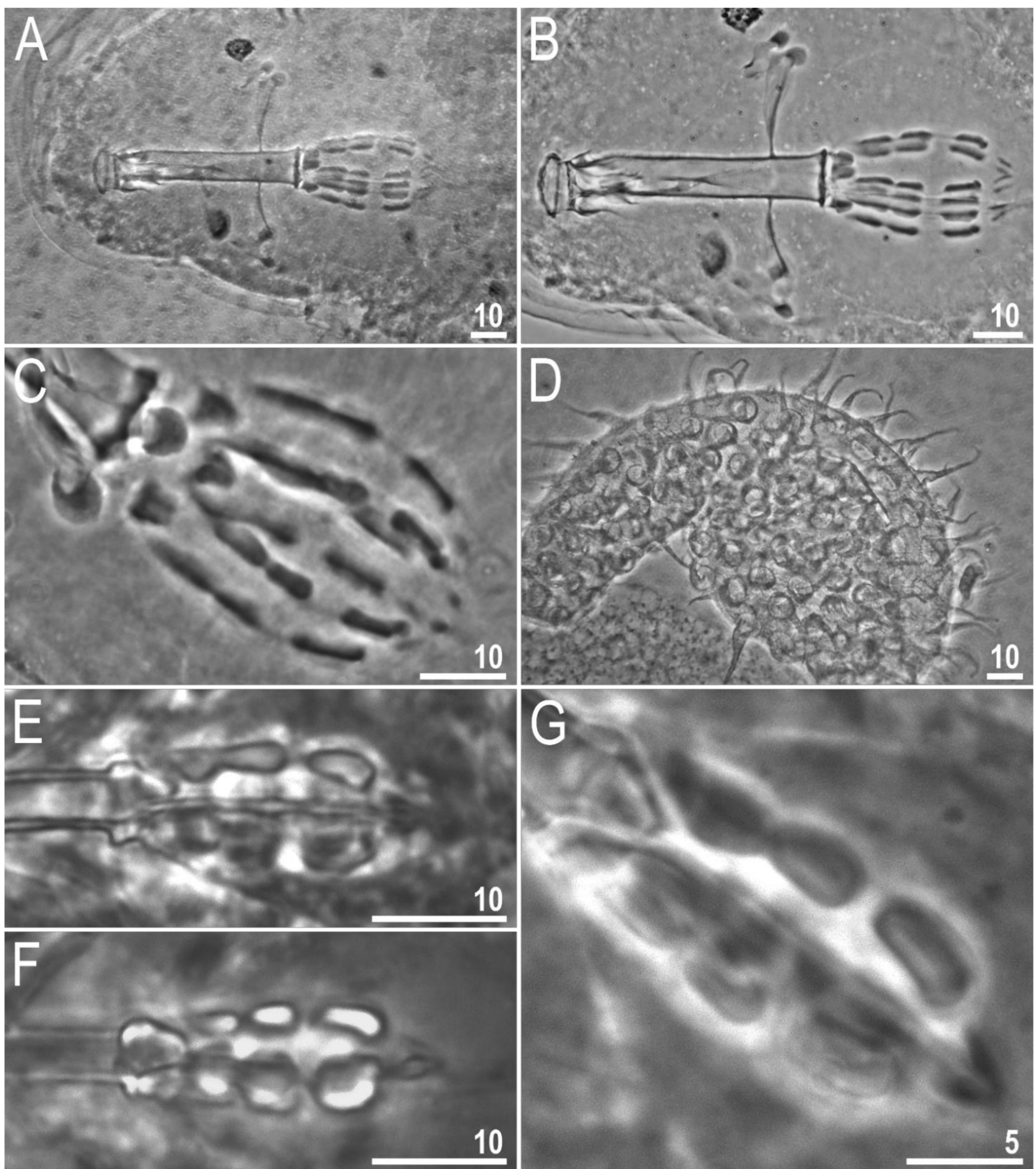

Figure 14. Tenuibiotus willardi (Maucci, 1982) and Tenuibiotus bozhkae Pilato, Kiosya, Lisi, Inshina \& Biserov, 2011 types: (A,B) T. willardi: Bucco-pharyngeal apparatus of the holotype (the Pilato and Binda collection); (C) T. willardi: Placoids of the paratype (the Bertolani collection); (D) T. willardi: Egg (the Pilato and Binda collection); (E) T. bozhkae: Placoids of the holotype (the Pilato and Binda collection); $(\mathrm{F}, \mathrm{G})$ T. bozhkae: Placoids of the paratype (the Pilato and Binda collection). Scale bars in $\mu \mathrm{m}$.

Interestingly, the latter species exhibits two macroplacoids in the pharynx, with the first one being extremely deeply constricted in the middle ([97]; Figure 3B). Although the quality of morphological documentation is much better in Guil et al. [97], the comparison of microphotographs presented in both these papers reveals that there is no obvious 
difference between them in this particular character $([89,97]$, especially the comparison of Figures $2 \mathrm{~B}$ and $3 \mathrm{~B}$, respectively). The examination of additional microphotographs of the holotype and paratype of T. bozhkae (Figure 14E-G) also did not allow us to indicate a clear difference between this species and T. ciprianoi. Thus, we consider T. bozhkae to possess only two macroplacoids in the pharynx, with the first one being deeply constricted. Therefore, we propose a third, uniform diagnostic morphological character for the genus Tenuibiotus, which is the presence of two macroplacoids in the pharynx.

\section{Conclusions}

Our work is yet another example of the great value of the integrated approach at a taxonomic and phylogenetic level when studying groups of small organisms such as meiofauna that are known to have a limited number of informative morphological characteristics. In this case, the revision of one enigmatic species and the discussion induced thereafter led to important amendments for other tardigrade taxa. We greatly endorse continuous studies on tardigrade taxonomy that implement the analyses of detailed phenotypic information tightly linked to genetic data. Surely, these will not only bring discoveries of new, exciting taxa but will also help to elucidate the trajectories of morphological evolution within this group of microscopic animals.

Supplementary Materials: The following supporting information can be downloaded at: https://www.mdpi.com/article/10.3390/ani12030404/s1. SM.01. Best-fit partitioning schemes and models suggested by PartitionFinder; SM.02. Raw Bayesian and Maximum Likelihood trees given in Newick format; SM.03. Raw morphometric measurements of the topotypic population of T. hyperonyx. SM.04. Movie recording of an alive and gravid female of T. hyperonyx.

Author Contributions: Conceptualization, D.S.; investigation, D.S. and W.M.; resources, D.S.; visualization, D.S.; validation, D.S. and W.M.; writing—original draft preparation, D.S.; writing-review and editing, D.S. and W.M.; project administration, D.S.; data curation, D.S.; funding acquisition, D.S. All authors have read and agreed to the published version of the manuscript.

Funding: The study was supported by the Preludium program of the Polish National Science Centre (grant no. 2018/31/N/NZ8/03096 to D.S.). During this study, D.S. and W.M. were supported by the Foundation for Polish Science via START programme (FNP).

Institutional Review Board Statement: Not applicable.

Informed Consent Statement: Not applicable.

Data Availability Statement: The author confirms that the data supporting the findings of this study are available within the article and its Supplementary Materials. The DNA sequences generated in this study are available in GenBank.

Acknowledgments: We are grateful to Katarzyna Vončina for her assistance in sample collection and to Denis Tumanov, Oscar Lisi and Matteo Vecchi for providing the type microphotographs of different species analyzed in this study. We would also like to thank Roberto Guidetti and the Civic Museum of Natural History of Verona that made the Bertolani collection available for W.M. and Piotr Gasiotrek. Piotr Gasiorek is also gratefully acknowledged for buccal-pharyngeal apparatuses extraction, recording the movie as well as his comments to the first version of our manuscript. We would also like to express our gratitude for the two anonymous reviewers whose suggestions helped us to improve the manuscript.

Conflicts of Interest: The authors declare no conflict of interest. The funders had no role in the design of the study; in the collection, analyses, or interpretation of data; in the writing of the manuscript, or in the decision to publish the results.

\section{References}

1. Nelson, D.R.; Bartels, P.J.; Guil, N. Tardigrade Ecology. In Water Bears: The Biology of Tardigrades; Schill, R.O., Ed.; Springer: Basel, Switzerland, 2019; pp. 163-210. [CrossRef]

2. Guidetti, R.; Bertolani, R. Tardigrade taxonomy: An updated check list of the taxa and a list of characters for their identification. Zootaxa 2005, 845, 1-46. [CrossRef] 
3. Degma, P.; Guidetti, R. Notes to the current checklist of Tardigrada. Zootaxa 2007, 1579, 41-53. [CrossRef]

4. Degma, P.; Bertolani, R.; Guidetti, R. Actual Checklist of Tardigrada Species (2009-2021, Ver. 40: 19-07-2021); Universita di Modena e Reggio Emilia: Modena, Italy, 2021. [CrossRef]

5. Surmacz, B.; Morek, W.; Michalczyk, Ł. What if multiple claw configurations are present in a sample: A case study with the description of Milnesium pseudotardigradum sp. nov. with unique developmental variability. Zool. Stud. 2019, 58, 32. [CrossRef]

6. Bochnak, M.; Vončina, K.; Kristensen, R.M.; Gąsiorek, P. Continued exploration of Tanzanian rainforests reveals a new echiniscid species (Heterotardigrada). Zool. Stud. 2020, 59, 18. [CrossRef]

7. Kayastha, P.; Berdi, D.; Mioduchowska, M.; Gawlak, M.; Łukasiewicz, A.; Gołdyn, B.; Jędrzejewski, S.; Kaczmarek, Ł. Description and molecular characterization of Richtersius ziemowiti sp. nov. (Richtersiidae) from Nepal (Asia) with evidence of heterozygous point mutation events in the 28S rRNA. Ann. Zool. 2020, 70, 381-396. [CrossRef]

8. Tumanov, D.V. Integrative description of Mesobiotus anastasiae sp. nov. (Eutardigrada, Macrobiotoidea) and first record of Lobohalacarus (Chelicerata, Trombidiformes) from the Republic of South Africa. Eur. J. Taxon. 2020, 726, 102-131. [CrossRef]

9. Tumanov, D.V. Integrative redescription of Hypsibius pallidoides Pilato et al., 2011 (Eutardigrada: Hypsibioidea) with the erection of a new genus and discussion on the phylogeny of Hypsibiidae. Eur. J. Taxon. 2020, 681, 1-37. [CrossRef]

10. Stec, D.; Dudziak, M.; Michalczyk, Ł. Integrative descriptions of two new Macrobiotidae species (Tardigrada: Eutardigrada: Macrobiotoidea) from French Guiana and Malaysian Borneo. Zool. Stud. 2020, 59, 23. [CrossRef]

11. Guidetti, R.; Schill, R.O.; Giovannini, I.; Massa, E.; Goldoni, S.E.; Ebel, C.; Förschler, M.I.; Rebecchi, L.; Cesari, M. When DNA sequence data and morphological results fit together: Phylogenetic position of Crenubiotus within Macrobiotoidea (Eutardigrada) with description of Crenubiotus ruhesteini sp. nov. J. Zool. Syst. Evol. Res. 2021, 59, 576-587. [CrossRef]

12. Vecchi, M.; Stec, D. Integrative descriptions of two new Macrobiotus species (Tardigrada, Eutardigrada, Macrobiotidae) from Mississippi (USA) and Crete (Greece). Zoosyst. Evol. 2021, 97, 281-306. [CrossRef]

13. Stec, D.; Morek, W.; Gąsiorek, P.; Michalczyk, Ł. Unmasking hidden species diversity within the Ramazzottius oberhaeuseri complex, with an integrative redescription of the nominal species for the family Ramazzottiidae (Tardigrada: Eutardigrada: Parachela). Syst. Biodivers. 2018, 16, 357-376. [CrossRef]

14. Guidetti, R.; Cesari, M.; Bertolani, R.; Altiero, T.; Rebecchi, L. High diversity in species, reproductive modes and distribution within the Paramacrobiotus richtersi complex (Eutardigrada, Macrobiotidae). Zool. Lett. 2019, 5, 1. [CrossRef] [PubMed]

15. Cesari, M.; Montanari, M.; Kristensen, R.M.; Bertolani, R.; Guidetti, R.; Rebecchi, L. An integrated study of the biodiversity within the Pseudechiniscus suillus-facettalis group (Heterotardigrada: Echiniscidae). Zool. J. Linn. Soc. 2020, 188, 717-732. [CrossRef]

16. Grobys, D.; Roszkowska, M.; Gawlak, M.; Kmita, H.; Kepel, A.; Kepel, M.; Parnikoza, I.; Bartylak, T.; Kaczmarek, Ł. High diversity in the Pseudechiniscus suillus-facettalis complex (Heterotardigrada; Echiniscidae) with remarks on the morphology of the genus Pseudechiniscus. Zool. J. Linn. Soc. 2020, 188, 733-752. [CrossRef]

17. Stec, D.; Krzywański, Ł.; Zawierucha, K.; Michalczyk, Ł. Untangling systematics of the Paramacrobiotus areolatus species complex by an integrative redescription of the nominal species for the group, with multilocus phylogeny and species delineation within the genus Paramacrobiotus. Zool. J. Linn. Soc. 2020, 188, 694-716. [CrossRef]

18. Stec, D.; Krzywański, Ł.; Arakawa, K.; Michalczyk, Ł. A new redescription of Richtersius coronifer, supported by transcriptome, provides resources for describing concealed species diversity within the monotypic genus Richtersius (Eutardigrada). Zool. Lett. 2020, 6, 2. [CrossRef] [PubMed]

19. Stec, D.; Vecchi, M.; Dudziak, M.; Bartels, P.J.; Calhim, S.; Michalczyk, Ł. Integrative taxonomy resolves species identities within the Macrobiotus pallarii complex (Eutardigrada: Macrobiotidae). Zool. Lett. 2021, 7, 9. [CrossRef]

20. Bertolani, R.; Guidetti, R.; Marchioro, T.; Altiero, T.; Rebecchi, L.; Cesari, M. Phylogeny of Eutardigrada: New molecular data and their morphological support lead to the identification of new evolutionary lineages. Mol. Phylogenet. Evol. 2014, 76, 110-126. [CrossRef]

21. Cesari, M.; Vecchi, M.; Palmer, A.; Bertolani, R.; Pilato, G.; Rebecchi, L.; Guidetti, R. What if the claws are reduced? Morphological and molecular phylogenetic relationships of the genus Haplomacrobiotus May, 1948 (Eutardigrada, Parachela). Zool. J. Linn. Soc. 2016, 178, 819-827. [CrossRef]

22. Guidetti, R.; Rebecchi, L.; Bertolani, R.; Jönsson, K.I.; Kristensen, R.M.; Cesari, M. Morphological and molecular analyses on Richtersius (Eutardigrada) diversity reveal its new systematic position and lead to the establishment of a new genus and a new family within Macrobiotoidea. Zool. J. Linn. Soc. 2016, 178, 834-845. [CrossRef]

23. Gassiorek, P.; Morek, W.; Stec, D.; Michalczyk, Ł. Untangling the Echiniscus Gordian knot: Paraphyly of the "arctomys group" (Heterotardigrada: Echiniscidae). Cladistics 2019, 35, 633-653. [CrossRef] [PubMed]

24. Gąsiorek, P.; Stec, D.; Morek, W.; Michalczyk, Ł. Deceptive conservatism of claws: Distinct phyletic lineages concealed within Isohypsibioidea (Eutardigrada) revealed by molecular and morphological evidence. Contrib. Zool. 2019, 88, 78-132. [CrossRef]

25. Gąsiorek, P.; Michalczyk, Ł. Phylogeny of Itaquasconinae in light of the evolution of the flexible pharyngeal tube in Tardigrada. Zool. Scr. 2020, 49, 499-515. [CrossRef]

26. Morek, W.; Michalczyk, Ł. First extensive multilocus phylogeny of the genus Milnesium Doyère, 1840 (Tardigrada) reveals no congruence between genetic markers and morphological traits. Zool. J. Linn. Soc. 2020, 188, 681-693. [CrossRef]

27. Stec, D.; Vecchi, M.; Maciejowski, W.; Michalczyk, Ł. Resolving the systematics of Richtersiidae by multilocus phylogeny and an integrative redescription of the nominal species for the genus Crenubiotus (Tardigrada). Sci. Rep. 2020, 10, 19418. [CrossRef] 
28. Morek, W.; Surmacz, B.; López-López, A.; Michalczyk, Ł. "Everything is not everywhere": Time-calibrated phylogeography of the genus Milnesium (Tardigrada). Mol. Ecol. 2021, 30, 3590-3609. [CrossRef]

29. Stec, D.; Vecchi, M.; Calhim, S.; Michalczyk, Ł. New multilocus phylogeny reorganises the family Macrobiotidae (Eutardigrada) and unveils complex morphological evolution of the Macrobiotus hufelandi group. Mol. Phylogenet. Evol. 2021, $160,106987$. [CrossRef]

30. Tumanov, D.V. End of a mystery: Integrative approach reveals the phylogenetic position of an enigmatic Antarctic tardigrade genus Ramajendas (Tardigrada, Eutardigrada). Zool. Scr. 2022. [CrossRef]

31. Stec, D.; Roszkowska, M.; Kaczmarek, Ł.; Michalczyk, Ł. An integrative description of a population of Mesobiotus radiatus (Pilato, Binda and Catanzaro, 1991) from Kenya. Turk. J. Zool. 2018, 42, 523-540. [CrossRef]

32. Morek, W.; Blagden, B.; Kristensen, R.M.; Michalczyk, Ł. The analysis of inter- and intrapopulation variability of Milnesium eurystomum Maucci, 1991 reveals high genetic divergence and novel type of ontogenetic variation (Tardigrada: Apochela). Syst. Biodivers. 2020, 18, 614-632. [CrossRef]

33. Morek, W.; Surmacz, B.; Michalczyk, Ł. Novel integrative data for two Milnesium Doyère, 1840 (Tardigrada: Apochela) species from Central Asia. Zoosyst. Evol. 2020, 96, 499-514. [CrossRef]

34. Pogwizd, J.; Stec, D. New records of Dactylobiotus parthenogeneticus Bertolani, 1982 provide insight into its genetic variability and geographic distribution. Folia Biol. 2020, 68, 57-72. [CrossRef]

35. Stec, D.; Kristensen, R.M.; Michalczyk, Ł. An integrative description of Minibiotus ioculator sp. nov. from the Republic of South Africa with notes on Minibiotus pentannulatus Londoño et al., 2017 (Tardigrada: Macrobiotidae). Zool. Anz. 2020, 286, 117-134. [CrossRef]

36. Kiosya, Y.; Pogwizd, J.; Matsko, Y.; Vecchi, M.; Stec, D. Phylogenetic position of two Macrobiotus species with a revisional note on Macrobiotus sottilei Pilato, Kiosya, Lisi \& Sabella, 2012 (Tardigrada: Eutardigrada: Macrobiotidae). Zootaxa 2021, 4933, $113-135$. [CrossRef]

37. Tumanov, D.V. Presence of Notahypsibius pallidoides (Tardigrada: Hypsibiidae) in the fauna of Russia confirmed with the methods of DNA barcoding. Biol. Commun. 2021, 66, 274-280. [CrossRef]

38. Jørgensen, A.; Kristensen, R.M.; Møbjerg, N. Phylogeny and Integrative Taxonomy of Tardigrada. In Water Bears: The Biology of Tardigrades; Schill, R.O., Ed.; Springer: Basel, Switzerland, 2019; pp. 95-114. [CrossRef]

39. Gasiorek, P.; Vončina, K.; Nelson, D.R.; Michalczyk, Ł. The importance of being integrative: A remarkable case of synonymy in the genus Viridiscus (Heterotardigrada: Echiniscidae). Zool. Lett. 2021, 7, 13. [CrossRef]

40. Maucci, W. Sulla presenza in Italia di Cornechiniscus holmeni (Petersen, 1951), e descrizione di Macrobiotus hyperonyx sp. nov. Boll. Mus. Civ. Stor. Nat. Verona 1982, 9, 175-179.

41. Maucci, W. A contribution to the knowledge of the North American Tardigrada with emphasis on the fauna of Yellowstone National Park (Wyoming). In Biology of Tardigrada. Selected Symposia and Monographs, U.Z.I., Mucci Modena; Bertolani, R., Ed.; Mucchi Editore: Modena, Italy, 1987; pp. 187-210.

42. Maucci, W. Tardigradi della Mongolia Esterna, con Descrizione di Macrobiotus mongolicus sp. nov. Boll. Mus. Civ. Stor. Nat. Verona 1988, 14, 339-349.

43. Tumanov, D.V. Two new species of Macrobiotus (Eutardigrada, Macrobiotidae) from Tien Shan (Kirghizia), with notes on Macrobiotus tenuis group. Zootaxa 2005, 1043, 33-46. [CrossRef]

44. Tumanov, D.V. Three new species of Macrobiotus (Eutardigrada, Macrobiotidae, tenuis-group) from Tien Shan (Kirghizia) and Spitsbergen. J. Limnol. 2007, 66, 40-48. [CrossRef]

45. Pilato, G.; Lisi, O. Tenuibiotus, a new genus of Macrobiotidae (Eutardigrada). Zootaxa 2011, 2761, 34-40. [CrossRef]

46. Zawierucha, K.; Kolicka, M.; Kaczmarek, Ł. Re-description of the Arctic tardigrade Tenuibiotus voronkovi (Tumanov, 2007) (Eutardigrada; Macrobiotidea), with the first molecular data for the genus. Zootaxa 2016, 4196, 498-510. [CrossRef] [PubMed]

47. Stec, D.; Tumanov, D.V.; Kristensen, R.M. Integrative taxonomy identifies two new tardigrade species (Eutardigrada: Macrobiotidae) from Greenland. Eur. J. Taxon. 2020, 614, 1-40. [CrossRef]

48. Pilato, G. Macrobiotus willardi a new species of Tardigrada from Canada. Can. J. Zool. 1977, 55, 628-630. [CrossRef]

49. Stec, D.; Smolak, R.; Kaczmarek, Ł.; Michalczyk, Ł. An integrative description of Macrobiotus paulinae sp. nov. (Tardigrada: Eutardigrada: Macrobiotidae: Hufelandi group) from Kenya. Zootaxa 2015, 4052, 501-526. [CrossRef] [PubMed]

50. Petersen, B. The Tardigrade fauna of Greenland. A faunistic study with some few ecological remarks. Meddelser Grønland København 1951, 150, 5-94.

51. Doyère, M. Memoire sur les Tardigrades. Ann. Sci. Nat. 1840, 14, 269-362.

52. Casquet, J.T.; Thebaud, C.; Gillespie, R.G. Chelex without boiling, a rapid and easy technique to obtain stable amplifiable DNA from small amounts of ethanol-stored spiders. Mol. Ecol. Resour. 2012, 12, 136-141. [CrossRef]

53. Hall, T.A. BioEdit: A user-friendly biological sequence alignment editor and analysis program for Windows 95/98/NT. Nucleic Acids Symp. Ser. 1999, 41, 95-98.

54. Stec, D.; Zawierucha, K.; Michalczyk, Ł. An integrative description of Ramazzottius subanomalus (Biserov, 1985) (Tardigrada) from Poland. Zootaxa 2017, 4300, 403-420. [CrossRef]

55. Gąsiorek, P.; Stec, D.; Zawierucha, Z.; Kristensen, R.M.; Michalczyk, Ł. Revision of Testechiniscus Kristensen, 1987 (Heterotardigrada: Echiniscidae) refutes the polar-temperate distribution of the genus. Zootaxa 2018, 4472, 261-297. [CrossRef] 
56. Mironov, S.V.; Dabert, J.; Dabert, M. A new feather mite species of the genus Proctophyllodes Robin, 1877 (Astigmata: Proctophyllodidae) from the Long-tailed Tit Aegithalos caudatus (Passeriformes: Aegithalidae): Morphological description with DNA barcode data. Zootaxa 2012, 3253, 54-61. [CrossRef]

57. Astrin, J.; Stüben, P. Phylogeny in cryptic weevils: Molecules, morphology and new genera of western Palaearctic Cryptorhynchinae (Coleoptera: Curculionidae). Invertebr. Syst. 2008, 22, 503-522. [CrossRef]

58. Gąsiorek, P.; Stec, D.; Morek, W.; Michalczyk, Ł. An integrative redescription of Hypsibius dujardini (Doyère, 1840), the nominal taxon for Hypsibioidea (Tardigrada: Eutardigrada). Zootaxa 2018, 4415, 45-75. [CrossRef] [PubMed]

59. Guidetti, R.; Gandolfi, A.; Rossi, V.; Bertolani, R. Phylogenetic analysis of Macrobiotidae (Eutardigrada, Parachela): A combined morphological and molecular approach. Zool. Scr. 2005, 34, 235-244. [CrossRef]

60. Jørgensen, A.; Faurby, S.; Hansen, J.G.; Møbjerg, N.; Kristensen, R.M. Molecular phylogeny of Arthrotardigrada (Tardigrada). Mol. Phylogenet. Evol. 2010, 54, 1006-1015. [CrossRef] [PubMed]

61. Stec, D.; Arakawa, K.; Michalczyk, Ł. An integrative description of Macrobiotus shonaicus sp. nov. (Tardigrada: Macrobiotidae) from Japan with notes on its phylogenetic position within the hufelandi group. PLoS ONE 2018, 13, e0192210. [CrossRef] [PubMed]

62. Coughlan, K.; Michalczyk, Ł.; Stec, D. Macrobiotus caelestis sp. nov., a new tardigrade species (Macrobiotidae: Hufelandi group) from the Tien Shan mountains (Kyrgyzstan). Ann. Zool. 2019, 69, 499-513. [CrossRef]

63. Kaczmarek, Ł.; Zawierucha, K.; Buda, J.; Stec, D.; Gawlak, M.; Michalczyk, Ł.; Roszkowska, M. An integrative redescription of the nominal taxon for the Mesobiotus harmsworthi group (Tardigrada: Macrobiotidae) leads to descriptions of two new Mesobiotus species from Arctic. PLoS ONE 2018, 13, e0204756. [CrossRef]

64. Itang, L.A.M.; Stec, D.; Mapalo, M.A.; Mirano-Bascos, D.; Michalczyk, Ł. An integrative description of Mesobiotus dilimanensis, a new tardigrade species from the Philippines (Eutardigrada: Macrobiotidae: Furciger group). Raffles Bull. Zool. 2020, 68, $19-31$.

65. Guil, N.; Giribet, G. A comprehensive molecular phylogeny of tardigrades-Adding genes and taxa to a poorly resolved phylum-level phylogeny. Cladistics 2012, 28, 21-49. [CrossRef]

66. Kihm, J.H.; Kim, S.; McInnes, S.J.; Zawierucha, K.; Rho, H.S.; Kang, P.; Park, T.Y.S. Integrative description of a new Dactylobiotus (Eutardigrada: Parachela) from Antarctica that reveals an intraspecific variation in tardigrade egg morphology. Sci. Rep. 2020, 10, 9122. [CrossRef] [PubMed]

67. Altschul, S.F.; Gish, W.; Miller, W.; Myers, E.W.; Lipman, D.J. Basic local alignment search tool. J. Mol. Biol. 1990, 215 , 403-410. [CrossRef]

68. Guidetti, R.; Rebecchi, L.; Bertolani, R. Cuticule structure and systematics of Macrobiotidae (Tardigrada: Eutardigrada). Acta Zool. 2000, 81, 27-36. [CrossRef]

69. Bertolani, R.; Kristensen, R.M. New records of Eohypsibius nadjae, Kristensen, 1982, and revision of the taxonomic position of two genera of Eutardigrada (Tardigrada). Biol. Tardigrades 1987, 1, 359-372.

70. Katoh, K.; Misawa, K.; Kuma, K.; Miyata, T. MAFFT: A novel method for rapid multiple sequence alignment based on fast Fourier transform. Nucleic Acids Res. 2002, 30, 3059-3066. [CrossRef]

71. Katoh, K.; Toh, H. Recent developments in the MAFFT multiple sequence alignment program. Brief. Bioinform. 2008, 9, 286-298. [CrossRef] [PubMed]

72. Kumar, S.; Stecher, G.; Tamura, K. MEGA7: Molecular Evolutionary Genetics Analysis version 7.0 for bigger datasets. Mol. Biol. Evol. 2016, 33, 1870-1874. [CrossRef]

73. Vaidya, G.; Lohman, D.J.; Meier, R. SequenceMatrix: Concatenation software for the fast assembly of multi-gene datasets with character set and codon information. Cladistics 2011, 27, 171-180. [CrossRef]

74. Lanfear, R.; Frandsen, P.B.; Wright, A.M.; Senfeld, T.; Calcott, B. PartitionFinder 2: New methods for selecting partitioned models of evolution for molecular and morphological phylogenetic analyses. Mol. Biol. Evol. 2016, 34, 772-773. [CrossRef]

75. Lanfear, R.; Calcott, B.; Ho, S.Y.; Guindon, S. PartitionFinder: Combined selection of partitioning schemes and substitution models for phylogenetic analyses. Mol. Biol. Evol. 2012, 29, 1695-1701. [CrossRef]

76. Ronquist, F.; Huelsenbeck, J.P. MrBayes 3: Bayesian phylogenetic inference under mixed models. Bioinformatics 2003, 19, 1572-1574. [CrossRef]

77. Rambaut, A.; Suchard, M.A.; Xie, D.; Drummond, A.J. Tracer v1.6. 2014. Available online: http://beast.bio.ed.ac.uk/Tracer (accessed on 13 December 2017).

78. Stamatakis, A. RAxML version 8: A tool for phylogenetic analysis and post-analysis of large phylogenies. Bioinformatics 2014, 30, 1312-1313. [CrossRef] [PubMed]

79. Morek, W.; Stec, D.; Gąsiorek, P.; Schill, R.O.; Kaczmarek, Ł.; Michalczyk, Ł. An experimental test of eutardigrade preparation methods for light microscopy. Zool. J. Linn. Soc. 2016, 178, 785-793. [CrossRef]

80. Coughlan, K.; Stec, D. Two new species of the Macrobiotus hufelandi complex (Eutardigrada: Macrobiotidae) from Australia and India with notes on their phylogenetic position. Eur. J. Taxon. 2019, 573, 1-38. [CrossRef]

81. Eibye-Jacobsen, J. Are the supportive structures of the tardigrade pharynx homologous throughout the entire group? J. Zool. Syst. Evol. Res. 2001, 39, 1-11. [CrossRef]

82. Gasiorek, P.; Stec, D.; Morek, W.; Zawierucha, K.; Kaczmarek, Ł.; Lachowska-Cierlik, D.; Michalczyk, Ł. An integrative revision of Mesocrista Pilato, 1987 (Tardigrada: Eutardigrada: Hypsibiidae). J. Nat. Hist. 2016, 50, 2803-2828. [CrossRef] 
83. Stec, D.; Gąsiorek, P.; Morek, W.; Kosztyła, P.; Zawierucha, K.; Michno, K.; Kaczmarek, Ł.; Prokop, Z.M.; Michalczyk, Ł. Estimating optimal sample size for tardigrade morphometry. Zool. J. Linn. Soc. 2016, 178, 776-784. [CrossRef]

84. Michalczyk, Ł.; Kaczmarek, Ł. A description of the new tardigrade Macrobiotus reinhardti (Eutardigrada, Macrobiotidae, harmsworthi group) with some remarks on the oral cavity armature within the genus Macrobiotus Schultze. Zootaxa 2003, 331, 1-24. [CrossRef]

85. Kaczmarek, Ł.; Michalczyk, Ł. The Macrobiotus hufelandi (Tardigrada) group revisited. Zootaxa 2017, 4363, 101-123. [CrossRef]

86. Kaczmarek, Ł.; Cytan, J.; Zawierucha, K.; Diduszko, D.; Michalczyk, Ł. Tardigrades from Peru (South America), with descriptions of three new species of Parachela. Zootaxa 2014, 3790, 357-379. [CrossRef]

87. Pilato, G. Analisi di nuovi caratteri nello studio degli Eutardigradi. Animalia 1981, 8, 51-57.

88. Michalczyk, Ł.; Kaczmarek, Ł. The Tardigrada Register: A comprehensive online data repository for tardigrade taxonomy. J. Limnol. 2013, 72, 175-181. [CrossRef]

89. Pilato, G.; Kiosya, Y.; Lisi, O.; Inshina, V.; Biserov, V. Annotated list of Tardigrada records from Ukraine with the description of three new species. Zootaxa 2011, 3123, 1-31. [CrossRef]

90. Lisi, O.; Londoño, R.; Quiroga, S. Description of a new genus and species (Eutardigrada: Richtersiidae) from Colombia, with comments on the family Richtersiidae. Zootaxa 2020, 4822, 531-550. [CrossRef] [PubMed]

91. Richters, F. Tardigrada. In Handbuch der Zoologie; Kükenthal, W., Krumbach, T., Eds.; Walter de Gruyter \& Co.: Berlin/Leipzig, Germany, 1926; Volume 3, pp. 58-61.

92. Schuster, R.O.; Nelson, D.R.; Grigarick, A.A.; Christenberry, D. Systematic criteria of the Eutardigrada. Trans. Am. Microsc. Soc. 1980, 99, 284-303. [CrossRef]

93. Thulin, G. Über die Phylogenie und das System der Tardigraden. Hereditas 1928, 11, 207-266. [CrossRef]

94. Pilato, G.; Binda, M.G. Richtersius, nuove nome generico in sostituzione di Richtersia Pilato e Binda 1987 (Eutardigrada). Animalia 1989, 16, 147-148.

95. Maucci, W.; Ramazzotti, G. Adorybiotus gen. nov.: Nouva posizione sistematica per Macrobiotus granulatus Richters, 1903 e per Macrobiotus coronifer Richters, 1903 (Tardigrada, Macrobiotidae). Mem. Ist. Ital. Idrobiol. 1981, 39, 153-159.

96. Stec, D.; Vončina, K.; Kristensen, R.M.; Michalczyk, Ł. The Macrobiotus ariekammensis species complex provides evidence for parallel evolution of long claws in macrobiotid tardigrades. Zool. J. Linn. Soc. 2022. [CrossRef]

97. Guil, N.; Guidetti, R.; Machordom, A. Observations on the "tenuis group" (Eutardigrada, Macrobiotidae) and description of a new Macrobiotus species. J. Nat. Hist. 2007, 41, 2741-2755. [CrossRef] 